\title{
Evaluation of Board Reforms: An Examination of the Appointment of Outside Directors
}

\author{
Byung S. MIN \\ Griffith Business School \\ Griffith University, \\ 170 Kessels Rd, Nathan, Brisbane, Qld, Australia \\ b.min@griffith.edu.au \\ Tel: 6173735 5248; Fax: 61737355111
}

\begin{abstract}
Existing literature on the evaluation of the economic consequences of board reforms has some limitations including: their estimation results fail to show the causal effects of the regulatory reforms; they have limited policy implications for an economy where family businesses are dominant; and there is a lack of consensus on the impacts of the reforms.

Using a unique dataset and program evaluation methodologies, this paper investigated the performance of share prices in response to the newly introduced outside director system in Korea, where family businesses have been dominant. First, we find that the positive impact of the appointment of outside directors on returns is observed only when the proportion of outsiders on a board increases significantly and their appointment is accompanied by the lead-and-lag effect of regulatory reforms. Second, the buy-and-hold abnormal return is more evident for independent firms than for chaebol affiliates, due partly to the high monitoring costs for crossshareholdings among affiliates.

JEL Classification: G34; G38

Key words: Corporate governance; Outside director; Regulation; Chaebol; Policy evaluation

This paper was circulated under the title of Evaluation of Board Reforms: An Examination of the Appointment of Outside Directors before finalisation. We are grateful to two anonymous referees' valuable comments. We are also grateful to Hideaki Mijajima, Shinichi Hirota, Yul O. Kwon, Kyung-Seo Park, Byung-Ho Kang, Myong Seo Kim, Yo Eun Kim, Anthony Selvanathan, Li Yan, and seminar participants at Waseda University, Korea University, and Korea Corporate Governance Service for valuable comments. Takeo Hoshi (Editor-in-Chief) and S-I Fukuda (Editor) kindly suggested some useful references. We also thank Karl Keesman for helping codification to clean data and Anne Platt for editorial assistance. Financial support was from the Griffith University Research Grant. The usual disclaimer applies.
\end{abstract}




\section{Introduction}

A series of corporate scandals in the U.S. at the beginning of the new millennium, including Enron, Tyco, and WorldCom, rekindled the issue of corporate governance reforms. As a result, the Sarbane-Oxley Act (SOX) was enacted in July 2002, and the NYSE and NASDAQ established a new corporate governance framework. One of the key components of this reform is the renewed emphasis on the importance of independent directors in order to improve a board's monitoring function.

Various studies have evaluated securities legislation, particularly in the case of the U.S. following the introduction of the SOX. The existing literature, however, has some limitations. First, existing studies show mixed results. Zhang (2007) reports negative cumulative abnormal returns for U.S. firms along the enactment of the SOX, which is similar to Benston (1973), Stigler (1964) for the case of the Securities Act of 1933 and 1934, and Ferris and Yan (2007) for the case of the SEC requirement. By contrast, Greenstone, Oyer and Vissing-Jorgensen (2006) show a positive effect for the 1964 Securities Act Amendment and Sokolyk (2011) reports positive effects for some anti-takeover provisions. ${ }^{1}$ Dixit (2009) also surveys some successful as well as failed examples of institutional changes and concludes that "much more research is needed before we attempt to generalise."

Second, in our view, few of these studies on the evaluated securities legislation report the direct economic consequences of the reforms even though Dey (2010) argues that the most important question to examine is 'what was the impact of SOX?' Abadie and Imben (2006) also

\footnotetext{
${ }^{1}$ Other examples include Chhaochharia and Grinstein (2007), and Linck, Netter, Yang (2009), Miyajima (2008), Park and Shin (2004), Mitsudome et al. (2008), and Gul, Srinidhi and Ng (2011). Lhuillery (2011) examined the impact of corporate governance practices on R\&D in France. Aman and Nguyen (2008) investigated the effect of corporate governance quality on share price in Japan.
} 
argue that evaluation of the average treatment effect of policy reform is an important issue for both academics and policy makers. It is difficult to determine the causal relationship from estimates using the traditional OLS estimator (or its simple extension) due mainly to its failure to address endogeneity problems such as self-selection bias.

Third, existing studies focus on the case of the U.S. and thus have limited implications for non-US economies, particularly for an economy such as Korea where family-run businesses dominate (Kim, 2006; Ananchotikul and Eichengreen, 2009)). Morck, Wolfenzen and Yeung (2005) illustrate the importance of family-controlled businesses. In fact, most economies outside the Anglo-American economic model have been dominated by family-run businesses. Doidge, Karolyi and Stulz (2007) argued that board composition and functions may differ across different legal, institutional and regulatory systems, and that an examination of the situations pertaining to other countries is therefore useful. Furthermore, Bebchuck and Weisbach (2010) suggested that failure to monitor a board's management could present an even greater problem in familycontrolled companies with controlling shareholders (CSH).

The objective of this paper is to investigate the causal relationship (i.e., impact) between a firm's market value and the changes to the corporate governance system in South Korea (hereafter, Korea). The case of Korea provides an excellent material for the evaluation of policy reform. Following the 1997 crisis, the Korean government, in consultation with the IMF and IBRD which provided Korea with rescue packages during the financial crisis, introduced new regulatory policies for corporate governance. As a result, Korean listed firms have experienced a significant change in corporate governance within a short period of time, which is unprecedented in the world. The reform aimed at rectifying failures in corporate governance by enhancing the board's monitoring function, along with other measures such as increasing management/CEO 
accountability, protecting (minority) shareholder rights, and improving managerial transparency and information disclosure.

The introduction of outside director(s) is a major feature of the changes to board regulation, which is similar to the requirement under the SOX in the U.S. ${ }^{2}$ In particular, the amended Listing Act and the Securities and Exchange Law require all listed firms to appoint outside directors to their boards. However, the effect of the policy reform on the value of firm is not unanimous (Brickly and Zimmerman, 2010). The Korean economy has traditionally been dominated by family-run business groups, as is the case in many other Asian countries and some European countries. In particular, large family-run business groups, known as chaebols, have played an important role in Korea. ${ }^{3}$

This paper is expected to contribute to the literature in the following ways. First, a study of the impact of securities legislation on the stock market in an emerging market where familyrun businesses are dominant will add value to the inconclusive results of existing studies on

\footnotetext{
${ }^{2}$ The major difference is that the SOX strengthened the importance of independent directors rather than a new introduction.

${ }^{3}$ The Korea Fair Trade Commission (KFTC) defines a business group as a group of companies that is effectively (i.e., de facto) controlled by a corporation or a person. A firm becomes an affiliate of a group if more than 30 percent of the shares of that firm belong to affiliates and/or a group's CSH. The KFTC also regards a firm as an affiliate of a group if the de facto relationship between the firm and the group is similar to that of other affiliates. Large family-run business groups are called chaebols. The share value of the 10 largest chaebols accounted for 42.03 percent of the total market value on the Korea Composite Stock Price Index (KOSPI) at the end of June 2008. Circular-type cross-ownership among affiliates and the CSHs' dominance over the board across all affiliates has been major characteristics of the chaebol. In contrast to the Japanese main bank system, enterprise group firms are dominant in Korea. Enterprise group firms refer to business groups linked to each other mainly through circular cross-holdings of equity between non-bank firms. In contrast to Singapore, where government ownership is significant, Korean publicly traded firms are largely owned by individuals or other firms.
} 
securities legislation as described above. Siebels and Knyphausen-Aufseb (2012) reports that family-businesses significantly differ from non-family firms in agency costs, competitive advantages or corporate governance structure. In particular, the powerful CSH distorts the traditional principal-agency relationship by changing the main issue from minority shareholder vs. management to $\mathrm{CSH}$ vs. minority shareholder.

Second, unlike most existing studies (Choi, Park and Yoo, 2007; Black, Jang and Kim, 2006; Min and Verhoeven, 2013), we use the treatment analysis method, which enables us to investigate the causal effect of policy reforms rather than the association between variables. ${ }^{4}$ Imbens and Wooldridge (2009) suggest that treatment analysis is one of the best ways for policy evaluations. Black and Kim (2012) is an exceptional case in this regard. ${ }^{5}$ However, our paper differs from this study in the following ways. First, in contrast with most existing papers covering up to 2004 annual data, we use a panel data set covering both annual and daily data between 1999 and 2007. This allows us to evaluate the effect of the regulatory reform as well as to investigate the sustainability of the policy event 'following' the regulatory reform. ${ }^{6}$ More

\footnotetext{
${ }^{4}$ An exception is Greenstone et al. (2006). Zhang (2010) also uses the counterfactual concept using non-U.S. firms' returns to calculate abnormal returns for U.S. firms. Choi, Park and Yoo (2007) examined the effect of the appointment of outside directors in Korea. However, our paper differs from them in the following three important perspectives. First, the goal of our paper is to find a causal relationship by addressing endogenity problem whereas Choi et al.'s (2007) was to find association between variables. Second, their sample consists of only 457-464 firms for the period from 1999 to 2002 whereas our sample covers all listed firms from 1999 to 2007. Third, Tobin's q is the dependent variable in Choi et al. (2007) and the continuously compounded return is the dependent variable in our paper. In similar veins, Black, Jang, and Kim (2006) examined the effect of board reform in Korea and show that the overall corporate governance 'index' constructed by the Korea Stock Exchange (KSE) in 2001 is useful in predicting share prices.

${ }^{5}$ This paper had not been published when the first version of our paper was circulated and presented at different universities in 2010.

${ }^{6}$ We use the long-horizon approach using nine years of data for the benchmark estimation. Gompers, Ishi, and Metrick (2003) suggest a long-horizon (9-10 years) approach to address the potential missing confounders and estimation bias.
} 
importantly, BK evaluates the effect of the 1999 amendment that requires 'large firms' to appoint outside directors for no less than 50 percent of board members whereas our paper addresses both the effects of the amended Listing Act in 1998 that requires 'all' listed firms to appoint outsiders at no less than 25 percent, as well as the 50 percent requirement. ${ }^{7}$ Consequently we expect to draw more generalised policy implications than existing studies.

We find that a positive impact of the appointment of outside directors is observed only when these appointments are significant at early stage of the reform and accompanied by the lead-and-lag impact of the legislative reform on corporate governance. Our paper does not support the dynamic sustainability of the direct impact of the appointments. The abnormal return during the appointment window is less evident for chaebol affiliates than for independent firms, due partly to the complicated ownership structures among affiliates and the consequent high costs for monitoring by outside directors.

The paper is organized as follows. In the next section, we summarize the new regulatory policy in relation to board structure following the 1997 crisis in Korea. Section 3 outlines the framework for the empirical estimation. Both the basic concepts of treatment analysis and

\footnotetext{
${ }^{7}$ There are more differences between Black and Kim (2012) and ours. (1) Identification of the event dates: For the event study, BK regards the multiple announcements of policies whereas our paper regards the date of Annual General Meeting. The appointment of outside directors is usually from the AGM. For the DID estimation, December 1999 is the dividing date for the evaluation in BK whereas any date of the appointment of outsiders is the dividing date in our paper. Treatment analysis usually prefers a specific date for individual firm-basis events to a broadly defined duration of event period. Furthermore, there could be a self-selection problem when we proxy the legislative date for the event date because Korean government offered a grace period for the compliance of the amended policies by 2000. (2) Formulation of counterfactuals: BK considers the performance of mid-sized firms as counterfactuals of the performance from treatment group, represented by large-sized firms. Treatment groups in BK are only a few numbers of selected firms (from 18 to 54 depending on models) because the 50 percent requirement is subjected only to large-sized firms (asset size is no less than 2 trillion won (=2billion USD)). Treatment group in our paper is comprised of any listed firms that appoint 'new' outside directors and the rest belongs to control group. Following the definition of the 'event' study and the treatment analysis, we consider the 'appointment' of outsiders represents 'receiving' the treatment. Alternatively, the effect of outsider director system can be evaluated using 'stock' value (i.e., net accumulated numbers) of the appointed outsiders. Traditional regression analysis is the most popular methodology for this examination (refer to Choi et al., 2007 and Min et al., 2013, among others). (3) Dependent variables in BK differ depending on models. Share return is always the dependent variable in our analysis,
} 
estimation issues, as well as our use of the KLCA dataset are described. Section 4 presents the estimation results including robustness checks. This section focuses on the effect of the appointment of outside directors on returns. Section 5 concludes the paper.

\section{Board Reforms and the Appointment of Outside Directors in Korea}

\subsection{The regulatory reforms}

Following the 1997 financial crisis, corporate governance reforms and governmentinitiated corporate restructuring were implemented in Korea. In the past, the internally appointed board members tended to act as rubber stamps and fail to monitor the actions of the CSHs, even when resources were being squandered due to tunnelling and empire building (Joh, 2003; Bae, Kang, and Kim, 2002; Durnev and Kim, 2005; Claessens, Djankov, and Lang, 2000). However, rapid economic growth in the absence of properly functioning corporate governance can increase the vulnerability of the economy to external shocks, as evidenced by the 1997 crisis (Mitton, 2002; Li, 2003).

Following the 1997 financial crisis, there were two major waves of reforms in relation to board structure in Korea. The first wave was largely aimed at establishing a foundation for the introduction of an outside director system, along with streamlining business focus among major chaebols. The second wave sought mainly to legalize the requirement for the improvement of corporate governance, including the outside director system.

In February 1998, the Listing Act was amended to require all listed firms excluding the Korean Securities Dealers Automated Quotations (KOSDAQ) to appoint at least one outside director and to ensure that no less than a quarter of their board members were outside directors 
by the time of the firm' AGM in 1999 (Art. 48.5). This means that the minimum number of outside directors for listed firms is one and the number of additional outside directors required is determined by the existing board size. We call this second requirement the 25 percent rule.

The second wave of reforms included amendments to the Securities and Exchange Law in March 2001 and December 2003. These revisions stipulate by law the 1998 Listing Act's requirement for outside directors (Art. 54.5) for all listed firms on both the Korea Exchange and the KOSDAQ (except for some venture capital companies). In practice, the government provided a grace period until 2000 for the implementation of the Listing Act, given the absence of a market for outside directors and to minimize adjustment costs for firms. However, the legal stipulation of this requirement means that the appointment of outside directors is no longer an option. These 2001 and 2003 amendments, based on the recommendations in the September 1999 Principles of Standard Corporate Governance and the Code of Best Practice of Corporate Governance, require:

- Large listed corporations to establish an Audit Committee and an Appointment Committee under the BOD comprised mainly of outside directors. A large firm is defined as a firm with an asset size of 2 trillion won (approximately 2 billion US\$) or more;

- The 2001 amendment also requires that no fewer than half the board members of large firms should be outside directors; and

- The 2003 amendments stipulate that large firms listed on the Korea Exchange and KOSDAQ should have at least three outside directors and at least half the positions on the board should be filled by outside directors.

We call the 2001 amendment the 50 percent rule for the purposes of our empirical estimation. 


\subsection{Empirical research hypothesis}

Theories on the effects of mandatory reforms of the board on firm value are inconclusive. The argument of 'tunnelling' by Johnson et al. (2000) suggest that the new law may lead to increase in firm value if firms appoint outside directors to minimise the private benefits of management (i.e., the captured board). The argument of the agency problem between the principal and the principal (Young et al., 2008) and Bebchuck and Weisbach (2010) indicate that the controlling shareholders $(\mathrm{CSH})$ in an economy dominated by family-business regard an independent board as a burden when seeking to implement business plans such as creating a business empire through investing and/or acquiring non-positive NPV projects. In addition to the minimising the entrenchments of manager/CSH, the resource dependence theory (Pfeffet and Salancik, 1978) and Adams and Ferreira's (2007) model illustrate that board reform can maximise benefits of outside directors as human capital.

If firms choose their board structure to maximise firm value, however, imposing binding legal constraints on their choice would move the optimal point to a sub-optimal point (Demsetz and Lehn, 1985). The path dependence theory (Bebchuk and Roe, 1999), similar to the Darwinism, argues that differences in governance structure in a country is accompanied with corresponding, other complementary organisational structures (Aoki and Jackson, 2008) and may have different comparative advantage in the use of different technology and competition in different markets. This path dependence theory implies that the effectiveness of mandatory reform could be constrained by existing market conditions in the economy. 
We hypothesize that shareholder value will rise with the appointment of outside directors to the extent of the market's expectation about the effective 'function' of the new board system in reducing managerial entrenchment.

\section{Analytical Framework, Data and Estimation Issues}

\subsection{The counterfactual framework}

The purpose of this paper is to investigate the causal effect of board reform, characterized by a firm's appointment of new outside directors, on the wealth of the owners of the firm, which is measured by the performance of the share price. To clarify the effect of the appointments, we classify firms with a new appointment as the treated group and other firms as the control group. Following the tradition (Imben and Wooldridge, 2009), we call the event of appointment of new outside directors the treatment or the appointment.

Share prices allow us to compute returns: returns on the treated firms $\left(R_{i t}^{1}\right)$ or returns on the non-treated (i.e., control) firms $\left(R_{i t}^{0}\right)$. The observed return, $R_{i t}$, is

$$
R_{i t}=R_{i t}^{0}+O D^{*}\left(R_{i t}^{1}-R_{i t}^{0}\right)
$$

where $O D=1$ if a firm appoints new outside directors, and $O D=0$ otherwise. The ultimate task of treatment analysis is to estimate the average treatment effect (ATE) and/or the average treatment effect on the treated (ATT).

$$
A T E \equiv E\left(R_{i t}^{1}-R_{i t}^{0}\right), \text { and }
$$


$A T T \equiv E\left(R_{i t}^{1}-R_{i t}^{0}\right), \quad$ only $\quad$ if $\quad i \in\{$ firms that appointed outside directors $\}$.

ATE in equation (2) is the expected abnormal return from the appointment of outside directors across the whole population, whereas ATT in equation (3) is the conditional expectation applying only to the treated sub-set (i.e., conditional on $O D=1$ ). Namely, the major difference between (2) and (3) is the target sample for the estimation. In principle, ATT is the sum of ATE and the perceived benefits of accepting the treatment. Thus, these two outcomes will be closer to the extent that self-selection bias can be ignored.

Because of the impossibility of observing both outcomes concurrently, the challenging task in the treatment literature is to estimate the counterfactual $R_{i t}^{0}\left(\right.$ or $\left.R_{i t}^{1}\right) .^{8}$ Namely, the question is to answer how the outcome of an average control group $\left(R_{i t}^{0}\right)$ would change if such an observation were to receive the treatment (i.e., appointment of outside directors), or if it was affected by change in a policy program (i.e., new regulation). Our estimations in Section V rely on the difference-in-difference estimator, treatment regression, the (matched) event study and the regression discontinuity design method. ${ }^{9}$

\subsection{The data}

Most annual information on firms listed on the Korea Exchange and daily share prices are obtained from the Korea Listed Companies Association (KLCA) database. Data on the disparity between ownership and control among chaebol affiliates are obtained from the Korea Fair Trade

\footnotetext{
${ }^{8}$ For example, the counterfactual of the unobservable $R_{i t}^{0}$ is the concern when we observe returns for the treated firm $R_{i t}^{1}$ and vice versa.

${ }^{9}$ The (matched) event study uses daily data whereas the others use annual data.
} 
Commission (KFTC) and Kang, Binh, Cho, and Yun (2007). The basic data sources for the KLCA database are business (semi-annual) reports, quarterly reports, and consolidated auditing reports, which are prepared and submitted by all listed corporations according to the Commercial Code and stock exchange laws. The average number of listed firms reached a high point of 776 in 1996, declining to 722 in 1999 and 666 in 2007. The decrease in the number of listed firms is attributed to the larger number of firms that existed in the market due to corporate restructuring following the Asian crisis in comparison to new entries. Our data set excludes firms that do not provide information about their assets or whose daily share price information is not available.

The KLCA database provides a wide range of corporate information, including balance sheet, income statement, stock price, auditor's opinion, and general information about stock exchange-listed and KOSDAQ-listed corporations. Our data set excludes KOSDAQ listed firms and financial companies in order to increase comparability between firms. Information about shareholders' AGM and board structure is obtained from the general information section. The Korea Corporate Governance Service (KCGS) also provides information about outside directors. However, our estimation is based on the KLCA database because the KCGS information is based on surveys, and thus the coverage of firms is limited and there is the possibility of measurement errors. The KCGS information is only available from 2002 and thus we cannot examine our hypothesis for the years prior to 2002.

The KLCA database provides information on the numbers of both outside directors and total board members from 1999. We identify both outside directors who have their own office in a firm as well as those who do not have their own office, although the majority of outside directors are external. Our data set ranges from 1999, when the firms began to appoint outside directors, to 2007, just before the onset of the global financial crisis following the U.S. subprime 
mortgage crisis. We use the 1999 data in the analysis of annual returns, such as the difference-indifference method. We exclude this 1999 data from our daily basis analysis because the AGM information is not available, and thus the timing of the announcement of outside directors cannot be verified.

\subsection{Compliance by firms and estimation issues}

Self-selection problem Listed firms began to appoint outside directors in 1999. In particular, as Table 1 shows, the proportion of listed firms with at least one outside director increased substantially from 34 percent in 1999 to 62.3 percent in 2000 . This significant rate of increase was repeated in 2003 and 2007. However, the rationale behind these dramatic increases may be different. The first increase resulted from the first wave of reforms, whereas the last two increases occurred after amendments to the Securities and Exchange Law made the requirement for outside directors legally binding. Hence, the appointment of outside directors during the first wave of reforms was somewhat discretionary. We notice that this voluntary element causes a biased estimation of the traditional OLS estimator. This endogeneity issue will be examined further in Section 5.

[Insert Table 1 around here]

Table 1 also shows that in 2007 around 94 percent of listed firms appointed at least one outside director, which represented a 60 percent increase over 1999. This increase can be attributed largely to the introduction of the new regulations described in Section 3 and the gradual development of a market for outside directors. The table also shows that the most common number of outside directors per firm was two. The term of an outside director in Korea 
is usually 2-3 years, and an appointment can be renewed for one more term. The last row indicates that the proportion of firms with at least three outside directors also increased sharply in 2000 .

The 25 percent rule versus the 50 percent rule

Figure 1 shows the trends in the size of BOD, the number of outside directors (left axis), and the ratio of outside directors to the BOD (right axis) between 1999 and 2007. It shows that the number of outside directors increased sharply in 2000 and in 2003 . The ratio of outside directors to the BOD has continued to increase, and reached 0.33 in 2007. The increasing ratio of outside directors to the BOD can be attributed to a combination of two factors. First, the average BOD size, as the denominator, dropped in the early 2000s. The average board sizes were around 6.5 in 1999 and 2000, compared to around 6 over the sample period as a whole. Second, the appointment of new outside directors, as the numerator, increased. Thus, the increase in the ratio of outside directors to the BOD resulted from firms' strategic choice to downsize their boards, combined with the appointment of outside directors to comply with the 50 percent rule for large firms and the 25 percent rule for other firms.

[Insert Figure 1 here]

Chaebol affiliates versus independent firms Panel A in Figure 2 shows that relatively more chaebol affiliates than independent firms have complied with the 50 percent rule. The affiliates' share of complying firms has consistently been nearly three times greater than that of independent firms since the early 2000s. The high rate of compliance by affiliates is consistent with the fact that chaebols are comprised of many large firms, which are therefore subject to the 
50 percent legal requirement. Panel B in Figure 2 also shows that the number of firms complying with the 25 percent rule increased sharply during 1998-2000 and 2001-2003, which is in line with the timing of the two major reforms to the regulatory regime. In contrast to the 50 percent rule, the pattern of compliance with the 25 percent rule was similar in chaebol affiliates and independent firms.

[Insert Figure 2 here]

In sum, the number of listed firms with at least one outside director has increased significantly in line with the amendments to the regulatory reforms and the announcement of the Rules and Principles in the early 2000s. Listed firms' compliance with the requirement for at least one outside director reached 94 percent in 2007. Consequently, the ratio of outside directors to total board size increased, particularly in 2000 . The 50 percent rule was largely complied with by chaebol affiliates due to their large size.

\section{Estimation and Results}

We use annual data to begin the analysis by the difference-in-difference (DID) method to control for the time invariant and macro confounders, followed by the treatment regression method to address the potential endogeneity (self-selection) bias. The treatment regression method provides information about a firm's decision in relation to outside appointments. We also use daily data in the second part of this section to measure the abnormal returns after controlling for firm-specific characteristics. We then conduct further robustness tests. 


\subsection{Baseline estimation}

The difference-in-difference (DID) method is a simple but powerful method to control for time invariant and macro confounding that affect the treated and control groups in the same way over two periods of time (refer to Appendix 1). We classify these two time periods as before $(t)$ and after the treatment $(t+1)$. The appointment effect on the return, $\delta$, is measured by $E\left(R_{i, t+1}^{1}-R_{i, t}^{1}\right)-E\left(R_{i, t+1}^{0}-R_{i, t}^{0}\right)$, where the first and second parts capture the difference within the treatment group and the difference within the control group, respectively. These within differences still cannot remove confounding caused by changes in macroeconomic conditions that affect the two groups simultaneously. Thus, we need one more difference to remove the noise caused by macro conditions, and this difference explains the name of the method.

We regress the response variable of the return to capitalize the statistical characteristics of the regression coefficient of the interaction between the two binary variables:

$$
E\left(R_{i t} \mid O D, \text { Time }\right)=\text { const }+\beta_{1} \cdot T_{t}+\beta_{2} \cdot O D_{i}+\delta \cdot T_{t} \times O D_{i}
$$

Where the binomial variable $T_{\mathrm{t}}$ is unity if $t \in\{$ post appointment time $\}$ and zero otherwise. Similarly, the binomial variable $O D_{i}$ (i.e., the treatment indicator) is unity if $i \in\{$ firms which appointed new outside directors $\}$ and zero otherwise.

For estimation purposes, we divide the nine years of panel data into eight sub-panel sets (pairs), where each pair is comprised of two consecutive years. Thus, the analysis is a type of cross-sectional time-series analysis rather than a traditional longitudinal data analysis. This concept is in line with Gompers, Ishi, and Metrick's (2003) suggestion of a long-horizon approach to address the limitations of the traditional event study method without identifying the exact event date. Following the spirit of the treatment analysis, we consider the appointment of outside director(s) is the criteria to divide treatment and control groups in each paired year. On Panel A in Table 2, for example, a firm belongs to the treatment group (i.e., $O D^{+}=1$ ) when this firm appointed outsider(s) between 1999 and 2000 (i.e., the first pair). However, this firm may 
become a subset of control group on Panel B if the firm did not increase the number of outsiders. As a result, the portions of treatment group vary between 11 and 30 percent depending on the pair.

- Treatment group $\left(O D^{+}=1\right)$ : if a firm appoint outside director(s) within the selected (consecutive) paired years

- Control group $\left(O D^{+}=0\right)$ : if a firm does not increase outside director(s) within the (consecutive) selected paired years

The response (i.e., dependent) variable is the return calculated by the natural logarithm of the ratio of share price at the end of two consecutive years. Treatment effect is captured by the coefficient of the interaction variable, $\delta$, in equation (4). In our estimation, we replace $\delta$ with $\delta_{-} O D^{+}$to signify the effect of appointment of outside director(s). In Table 2 we estimate the coefficient $\left(\delta_{-} O D^{+}\right)$of the interaction between the two binary variables, treatment time $(T)$ and new appointment of outside directors $\left(O D^{+}\right)$.

- $\delta_{-} O D^{+}$: Post Appointment Time $(T) \times$ New Appointment of Outside Director within a pair $\left(O D^{+}\right)$

Where post appointment time $(T)$ equls to unity if time belongs to the later year of the each pair and zero otherwise. While our main concern is to examine whether or not there exists positive effects by the new appointment, we notice that firms may drop the number of outsiders within a paired year. Thus, we created another binary variable for this (negative) treatment $\left(\delta_{-} O D^{-}\right)$ similar to $\delta_{-} O D^{+} . \delta_{-} O D^{-}=1$ if a firm decreases the number of outsider within the paired years and 0 otherwise. The portions of treatment groups for this decrease vary 3-9 percent of our sample. 
We also generated two additional binary variables $\delta_{-} O D^{50 \%}$ and $\delta_{-} O D^{25 \%}$, where $\delta_{-} O D^{25 \%}\left(\delta_{-} O D^{50 \%}\right)$ equals to one if a firm appoints outsiders no less than 25 (50) percent of board members within the paired years and 0 otherwise. Following the 25 percent statutory requirement, the portion of treatment group (i.e., $\delta_{-} O D^{25 \%}=1$ ) has increased from 38 percent in the first pair to 87 percent in the last pair. The portion of the treatment group for the 50 percent rule stayed at around 5 percent of the sample.

Each of these cases represents a model (1) to (4) in each panel of Table 2, which presents selected sub-sets for brevity (full results are available). The estimation results in Panel A of Table 2 show that none of these coefficients is significant between 1999 and 2000. While the amended Listing Act of 1998 requires all listed firms to appoint outside directors, the performance of the share prices fails to capture this regulatory reform. The market's failure to value the outside director system can be associated with the poorly developed market for outside directors when the new system was first introduced. The 1998 Listing Act was also not legally binding until the introduction of the amendments to the Securities and Exchange Law in 2001 and 2003. Hence, we continue this investigation for the remaining years.

[Insert Table 2 here]

In contrast to the result for the period 1999-2000 in Panel A, the appointment of new outside directors affects the returns positively for the two paired years: 2000-2001 in Panel B and 2003-2004 in Panel C. The coefficient of $\delta_{-} O D^{+}$in Panel B shows that the new appointments raised returns by 10.3 percent per annum between 2000 and 2001. This positive impact is consistent with the finding by Choi, Park and Yoo (2007) who used sample for the period 1999- 
2002. The coefficient for years 2003-2004 in Panel C also confirms this positive effect, although the magnitude is somewhat smaller. Apart from these two cases, however, no other coefficient for any other years is significant.

A natural question to ask would be why the positive effect of new appointments is observed for only the two paired years 2000-2001 and 2003-2004. We note first that the number of outside directors compared to board members increased sharply during both these periods. This increase in appointments may have generated externalities for the treated and control groups in different ways. However, the insignificant estimates for the paired period 2006-2007 in Panel $\mathrm{D}$, which also experienced an increase in appointments, suggests that this externality may not provide the whole answer. ${ }^{10} \mathrm{We}$ also observe that major policies on board reform were announced in the early 2000s. In early 2001 and late 2003, the Securities and Exchange Law was amended. These amendments to the Securities and Exchange Law stipulate the 1998 Listing Act's requirement for the appointment of outside directors. The lead-and-lag effects of this legally binding regulatory reform, coupled with the rapid rise in the ratio of outside directors to total board members, can explain the limited observation of the positive effects of the appointments on the return. Secondly, similar to the concept of diminishing marginal returns, marginal productivity of outside directors could have declined as the numbers increase. This increased numbers of 'outsiders' might have caused coordination among board members to be more difficult. Thirdly, the rapidly increased demand for outside directors from all listed firms following the reform, combined with the underdeveloped market for outside directors, could have created a bottle-neck effect and thus increase in transaction costs of the appointment. Similarly, Ahern and Dittmar (2012) found the impact of firm valuation of mandated female

\footnotetext{
${ }^{10}$ None of the coefficients of the paired period 2004-2005 was significant and thus they were not reported for brevity.
} 
board representation in Norway to be negative and attributed the reason to the pressure in the market for female directors. Shareholders will discount the value of firm when they realise the increased transaction costs are burden to them.

We proceed further to examine some possible channels that the appointment of outside directors would induce the changes in the firm behaviour. ${ }^{11}$ Assuming that the performance of the firm would be affected as a result of the changes in the firm behaviour led by outside directors, we investigate the causality between the appointment of outside directors and the changes in business investment (measured by investment scaled by total asset), $R \& D$ activities (R\&D scaled by sales) and liquidity (liquidity scaled by asset). Firstly, we regress the investment on one-lagged outside_director (number of outsiders scaled by board members) without restricting sample (Estimation I). The estimated coefficient of outside_director was 0.03 (pvalue $=0.029$ ). To check the reverse direction of the causality, we regress the outside director on the one-lagged investment. However, the estimated coefficient of investment from this reversed regression (Estimation II) was not significant (p-value=0.192). These results of Estimations (I) and (II) imply that the appointment of outside director affects the firm's investment without reverse causality. Having noticed that the positive effect of the appointment of outside director was observed largely between 1999 and 2003, we continued the Estimation (I) twice with different sub-samples: one is up to 2003(Estimation I_i) and the other is between 2004 and 2007 (Estimation I_ii). The estimated coefficient of outside_director from the first sub-sample was 0.039 and remained significant ( $\mathrm{p}$-value=0.038). In contrast, the estimated outside_director from

\footnotetext{
${ }^{11} \mathrm{We}$ appreciate two anonymous referees' addressing this examination. Further, as one of the referees indicated there are possible different effects of different characteristics of outsiders. However, data about characteristics of a newly appointed outsider is not available. Characteristics of outsiders for 2002-2006 are provided by the Korea Corporate Governance Service. This data is largely survey-based annual data. Min and Verhoeven's (2013) instrument variable estimation reports that different characteristics of outsider affect firm value through their effect on outsider's board activities.
} 
the second sub-sample was not significant ( $\mathrm{p}$-value=0.26). These findings are consistent with our results of the Difference-in-Differences analysis in Table 2 and suggest that the appointment of outside directors positively affected firm's behaviour to increase investment, which in turn affected firm performance. $^{12}$

\subsection{Controlling for endogeneity (self-selection)}

While the DID method is powerful for a simple estimation of the treatment effect, selfselection bias is a possible concern, particularly for the year 2000, which was the grace period for the requirement. If a firm decides to appoint an outside director because it foresees that this appointment will affect the share price, then the estimation results will be biased due to endogeneity. The latent variable model is popular for handling this self-selection issue. However, the traditional latent variable model is of little use for cases where the response variable for nontreated firms is missing or truncated. We instead consider a version of this latent variable model, the treatment regression, as follows:

$$
\begin{aligned}
& E\left(R_{1 i} \mid O D, \mathbf{x}\right)=\text { const }+\delta \cdot O D_{2 i}+\mathbf{x}_{1 i}^{\prime} \boldsymbol{\beta}_{2}+u_{i}, \\
& O D_{2 i}^{*}=\mathbf{x}_{1 i}^{\prime} \boldsymbol{\theta}_{1 j}+\mathbf{x}_{2 i}^{\prime} \boldsymbol{\theta}_{2 j}+v_{i},
\end{aligned}
$$

\footnotetext{
${ }^{12}$ We repeated this exercise for $R \& D$ and liquidity variables. However, we observed that both $R \& D$ and outside_director variables are positive and significant in both estimations (I) and (II), implying a reverse causality problem. We also found that neither liquidity nor outside_director variables are significant from estimations (I) and (II).
} 
where the binary variable $O D_{2 i}$ in the upper equation of (5) is unity if the latent equation is greater than zero (i.e., $O D_{2 i}^{*}>0$ ) and zero otherwise. ${ }^{13}$ The latent equation captures the treatment groups, which is defined in the same way as $\delta_{-} O D^{+}$in Table 2.

In contrast to most latent models where some responses are missing or truncated, the treatment regression model always observes the response variables, $E\left(R_{1 i} \mid O D=1, \mathbf{x}\right)$ and $E\left(R_{1 i} \mid O D=0, \mathbf{x}\right)$, irrespective of the treatment status of a firm, and thus fits better with the distribution of our data set than traditional latent models. ${ }^{14}$ Another benefit of treatment regression is that it provides estimation results for the firm's decision on the appointment of outside directors (i.e., its participation decision) within the same structure as the effect of the appointment on the outcome variable.

Panel A of Table 3 shows the effects of firms' decisions on board reform on returns in the year 2000 in columns (1) - (3). Panel B shows the determinants of the firm's choice on board reforms (i.e., participation). ${ }^{15}$ Using a multi-factor model, the return equation includes firm characteristics in addition to the treatment variable. The effect of appointments on returns is measured by the coefficient of the treatment variable, $\delta_{-} O D^{+}$, in the model, including the following regressors:

\footnotetext{
${ }^{13}$ The two errors terms $u$ and $v$ are assumed to be bivariate normal distribution with a correlation of $\rho$.

${ }^{14}$ Hence, the residual in the first equation in (5) is a vector: $u_{i}^{1}$ for the treated group and $u_{i}^{0}$ for the control group. Estimation is based on the assumption that these two residuals and the residual in the participation (latent) equation follow multivariate normal distribution with zero mean and covariance matrix including the covariance parameters reflecting the endogeneity of the treatment, covariance between the outcomes, and variance of the error (normalized to be unity) from the participation equation. We used STATA version 11 as the estimation software.

${ }^{15}$ Columns (1) and (1)' are estimated by treatment regression using the maximum likelihood method, whereas (2) and (3) are calculated by instrument variable using the GMM and LIML methods, respectively. Columns (4), (5), and (6) are estimated by the logit model, the Poisson model, and the negative binomial model, respectively.
} 
- treatment variable is 1 if the firm appoints new outside directors and 0 otherwise, and the coefficient $\delta_{-} O D^{+}$captures the appointment effect;

- $\quad$ size (Ln_size), measured by natural logarithm of equity capital, and its squared terms (Ln_size2);

- book to market ratio (Book/Market), measured by book value per share divided by the average market price per share; and

- performance (Performance), measured by the two-year average of industry-demeaned profits in assets.

The firm's participation equation in Panel B of Table 3 includes variables representing the firm's characteristics as well as its ownership structure. Their expected signs are provided in $\{$.$\} :$ $<$ Firm characteristics $>$

- firm size and its square, defined as above. We expect $\{+\}$ for the level and $\{-\}$ for the squared term;

- dummy indicating chaebol affiliates (D_affiliate). We expect $\{+\}$, considering the affiliates' access to potential outside directors and media pressure for chaebol reforms, particularly since the 1997 financial crisis;

- foreign debt (Foreign Debt), measured by foreign debt divided by total liabilities. The expected sign of this variable is $\{-\}$ due to Korean firms' borrowing from foreign banks;

- firm's reliance on banks (Bank Dependence), measured by borrowing divided by total liabilities. We predict that this will be $\{-\}$ because the appointment of outside directors is expected to lead to a firm's greater reliance on the capital market; 
- firm's reliance on the capital market (Capital Market Dependence), measured by bond financing divided by total liabilities. The expected sign is $\{+\}$ for the opposite reason to that for the firm's reliance on banks;

- firm's monopoly power (Market Power), measured by advertising expenditure divided by sales. We hypothesise that this will be $\{-\}$ to the extent that market competition substitutes for good corporate governance; and

- growth rate of employment (Employee Growth), measured by the ratio of change in the number of employees to total employment. The expected sign is $\{+\}$ in Korea, where a unitary board system without employee participation in the board is commonplace.

$<$ Ownership structure>

- bank share (Bank Share), measured by the ratio of bank-owned shares. We expect this to be $\{-\}$ for the same reason as that given for the firm's reliance on banks;

- cross-firm share (Crossfirm Share), measured by the ratio of stocks owned by other nonfinancial firms. The expected sign is $\{-\}$ because cross-ownership between firms is regarded as a barrier to the outside director system; and

- foreign investors' share (Foreigners Share), measured by the ratio of foreign investors' share ownership to total share ownership. We conjecture that this will be $\{+\}$ for the opposite reason to that for the cross-firm share.

The estimation results using the maximum likelihood method $\left(\delta_{-} O D^{+}\right.$in column 1$)$ imply that a firm's appointment of new outside directors increases its annual return by around 10 percent, which is significant at the 1 percent level. This positive effect is also confirmed by the GMM estimation ( $\delta_{-} O D^{+}$in col. 2 ), although the magnitude of the coefficient decreases 
somewhat to 6 percent, and by the limited information maximum likelihood estimation $\left(\delta_{-} O D^{+}\right.$ in col. 3) with a magnitude of 9 percent. Our estimation, however, fails to find any significant impact of other firm characteristics such as size, book to market, and past performance on the return. $^{16}$

As for the firm's appointment decision in Panel B of Table 3, column (1)' shows the structural estimation together with the return using the treatment regression. The endogeneity test on the binary variable $\delta_{-} O D^{+}$, as indicated by $\chi^{2}(1)$, suggests that the estimation model should consider endogeneity bias caused by the firm's selectivity. Thus, the structural estimation model (1) is preferred to the instrument variable estimation models (2) and (3). Further, the sign of $\rho$ is negative, which may imply that the firm's decision on the appointment of outside directors may be based on different reasons from the market's evaluation of the outside director system. For comparison, we also give estimates using the logit model [col. (4)], count regression models including the Poisson [col. (5)], and negative binomial regression [col. (6)].

[Insert Table 3 here]

The treatment regression estimates, as the preferred model, show that a firm's size and reliance on the capital market positively affect the firm's decision on the appointment of outside directors. By contrast, a high level of cross-firm shareholdings and banks' holdings of a firm's shares would inhibit that firm's decision to appoint outside directors. The negative effect of bank share is consistent with our prediction and is confirmed by non-structural models regardless of the estimation method used (col. 4-6). In contrast to the treatment regression, however, the non-

\footnotetext{
${ }^{16}$ The effect of the market return is submerged in the constant, which is not shown here for brevity.
} 
structural models show counter-intuitive outcomes for the ratio of high foreign debt due to endogeneity bias.

We continue this investigation for the remaining years and find that none of the results, except those for 2000, support the positive effects of the new appointments on returns. ${ }^{17}$

\subsection{Measuring the direct effect of appointments}

Next, we use daily data to address the potential bias due to possible cross-correlation with the long-range data and to identify the 'timing' of the appointments. Given the year 2000 daily data, we analyse the appointment effect in conjunction with measuring abnormal returns over the preset appointment window. ${ }^{18}$ For the length of the appointment window, we consider two offsetting effects: difficulty in identifying the direct appointment effect and the improvement in efficiency, by increasing the length. The (untabulated) point estimation results point to a window length of a week (i.e., seven calendar days) for the investigation of appointments, as four out of nine estimated coefficients within this length of window are significant at the conventional level. These significant coefficients are spread along the appointment date. We confirm that this preset length in our sample is in line with the rule of thumb principle in the literature on treatment analysis, which recommends 3-5 percent of sample size (Imbens and Lemieux, 2008, and references therein). We call this length the (benchmark) appointment window in our analysis.

${ }^{17}$ However, some caution should be exercised in interpreting this result. As described above, the appointment of outside directors after 2001 should theoretically be exogenous. In line with this ex ante expectation, the statistic of $\chi^{2}$ (1) for the null of exogeneity of the appointment variable in 2003 was 0.74 , and did not reject this hypothesis.

${ }^{18}$ A significant amount of time was spent in cleaning the data, due largely to incorrect AGM dates for some companies in the KLCA database. We attempted to examine the analysis for 2003 daily data. However, a significant amount of data on share price was unmatched and only 34 observations matched the AGM information. 
The significance of the estimated coefficients before the appointment day may reflect the investors' expectation and market efficiency in terms of information delivery to investors. Thus, we measure the buy-and-hold abnormal returns (BHAR) over the appointment window by combining the concept of matching from the treatment method. ${ }^{19}$ For this purpose, we keep firms only if they are observed within the appointment window, so the appointment effects discussed in this section represent average treatment on the treated (ATT) as in equation (3).

We consider geometric mean of the market portfolio to estimate the counterfactual, $R_{i t}^{0}$. In other words, the counterfactual for BHAR over the event window $\left(C F R \_B H A R\right)$ is calculated as a geometric mean of the $T$ period simple gross return:

$$
C F R_{-} B H A R_{i t}^{0}=\exp \left[\frac{1}{T} \sum_{t=1}^{T} \ln \left(1+R_{M P, t}^{0}\right)\right]-1,
$$

where $R_{M P, t}^{0}$ refers to the net return on market portfolio on each trading day $(t)$ until the end of the preset treatment window $(T)$. Calculation of abnormal return is straightforward once we define actual returns for each treated firm in the same way. To investigate the average impact of the appointment of outside directors on the performance of share prices across all sample observations, we regress the abnormal return on one.

Table 4 presents the measured abnormal returns for all firms (col. 1) and their division into chaebol affiliates (col. 2) and independent firms (col. 3). The positive 0.006 in column (1) for all firms refers to the BHAR over the seven calendar days of the appointment window when we use firm size as the characteristic to identify the matched portfolio with a view to calculating

\footnotetext{
${ }^{19}$ Kothari and Warner (2007) argue that the buy-and-hold abnormal return approach has recently become more popular than the calendar time Jensen-alpha method.
} 
counterfactuals. The sign and magnitude of this estimation are comparable with our previous finding, although the annualized returns (around 30 percent) are somewhat higher than those using other estimation methods. ${ }^{20}$

In contrast to the existing literature, however, the division of the firms into chaebol affiliates (col. 2) and independent firms (col. 3) provides an interesting result. Compared to insignificant results for chaebol affiliates, the abnormal return for independent firms when the size effect is controlled for increases by $0.7-0.8$ percent over the window of 7-9 days, which is equivalent to around 28-40 percent per annum.

This result indicates that the market had doubts about the effectiveness of the outside director system for chaebol affiliates. Reforms of a governance system are accompanied by various transaction costs such as searching for qualified candidates, payments to them, providing them with business information, and ensuring their efforts to contribute to the firm. Chaebol affiliates do not have a disadvantage relative to independent firms in terms of their financial ability to meet these expected costs and their access to potential outside directors. Given the evidence of chaebols' tunnelling (Joh, 2003; Bae, Kang, and Kim, 2002), the ex ante expected benefits to chaebol affiliates from the board reforms would be greater than those to independent firms. However, the effective functioning of the outside director system in chaebol affiliates depends greatly on their 'independence' from the chaebol's CSHs. The effectiveness of the system is also a function of the outside directors' willingness and ability to understand complicated business structures, given the circular cross-firm shareholdings and the extremely diverse nature of affiliates.

[Insert Table 4 here]

\footnotetext{
${ }^{20}$ This will be around 17-20 percent, assuming there are between 200 and 250 business days a year.
} 
To clarify the reason for the absence of a positive effect of the appointment of outside directors in chaebol affiliates, we continue the estimation of the BHAR after classifying the treated firms into two groups (i.e., high versus low) based on three (mean) characteristics in Table 5. Columns (1) and (2) in Table 5 show that firms with a low level of cross-shareholdings achieve a higher return than those with a high level of cross-shareholdings. The $\chi^{2}(1)$ statistic based on the Hausman test indicates that the difference in the estimated parameters between the two groups is significant at the conventional level. Firms with a low level of cross-shareholdings gain a higher return than those with a higher level of cross-shareholdings, which is one of the main characteristics of chaebols, as typically 20-36 percent of outstanding shares are owned by affiliates.

This ownership structure causes three main problems for corporate governance in Korea. First, the circular-shareholding among affiliates prevents market-based governance measures such as (hostile) mergers and acquisitions. Second, in contrast to the pyramidal (vertically linked) ownership structure that is common in emerging economies, a circular (horizontallylinked) ownership structure among affiliates is common for Korean chaebols. Consequently, identifying the internal ownership structure within a business group has been a challenging task. Duchin, Matsusaka, and Ozbas, 2010) report that the effectiveness of outside directors will diminishes when there is an increase in monitoring costs due to asymmetric information problems. The establishment of holding companies - defined as a company that owns no less than 50 percent of a corporation's shares in order to control the corporation - was prohibited until April 1999, when the government began to allow the practice.

Third, CSHs of chaebols have greater managerial control over the group than their ownership warrants due to the complex circular cross-ownership arrangements. The Korea Fair 
Trade Commission (KFTC) prohibits mutual investment between mother and daughter companies. However, most CSHs of chaebols maintained managerial control through circularownership arrangements $(\mathrm{A} \rightarrow \mathrm{B} \rightarrow \mathrm{C} \rightarrow \mathrm{A})$ when the KFTC banned mutual ownership $(\mathrm{A} \rightarrow \mathrm{B}$, $\mathrm{B} \rightarrow \mathrm{A})$.

Columns (3) and (4) in Table 5 show that the high disparity between ownership and control in chaebol affiliates cancels out the expected positive effect of outside appointments. This disparity is often observed in other countries where dual-class shares are allowed (La Porta, Lopez-de-Silanes, Shleifer, and Vishny, 2002). In contrast, the disparity in Korea is attributed largely to the circular ownership structure. The abnormal return is, however, not significant when the counterfactuals are calculated using returns from the performance-based matched portfolio.

Columns (5) and (6) in Table 5 show that the positive effect of outside appointments is more evident in firms with a larger number of superfluous board members, measured by the sum of the existing statutory auditors and seniority-based promoted board members, than in those with a smaller number. Such largely decorative board members are expected to be eliminated from boards after the introduction of the outside director system as illustrated by Figure 1. Board members who are promoted purely based on seniority simply increase the size of the board, thereby reducing the board's efficiency (Yermack, 1996). The amended Commercial Code and Securities and Exchange Act suggest the introduction of an Audit Committee under the board in place of the traditional auditor system.

[Insert Table 5 here]

In summary, these findings explain why there is no appointment effect for chaebol affiliates compared to independent firms. A high degree of circular cross-ownership between 
affiliates and the disproportionate power of CSHs seem to have prevented the expected positive effect of the appointment of outside directors from materializing, as argued both by Bebchuk and Weisbach (2010) and Armstrong, Guay and Weber (2010). A significant reduction in the size of the board by eliminating unproductive members following the reforms also seems to have led to a better-performing share price.

In Table 6, we examine whether the effect of the appointment of outside directors differs according to the level of foreign ownership (col. 1 and 2) amd the ratio of exports to sales (col. 3 and 4). All of these estimations are carried out in combination with different lengths of the appointment window (i.e., 7 and 9 days) and firm characteristics (i.e., firm size and performance) to identify the matched portfolio. The estimated coefficients in columns (1)-(4) suggest that there is little difference in the BHAR between high and low levels of foreign ownership and ratios of the firm's exports to sales, particularly when we control for the effect of firm size.

This finding rejects the hypothesis that a higher level of foreign ownership can substitute for an outside director system. With the removal of barriers to foreign ownership, particularly following the 1997 crisis, foreign ownership of listed Korean companies increased to around 36 percent in 2002 and 37.5 percent by the end of 2006, up from just 13 percent in 1996 . In line with the increase in ownership, some foreign investors, including the Sovereign Fund's attempted (hostile) acquisition of SK affiliates, attempted to discipline managements and/or CSHs. ${ }^{21}$ Our results imply that foreign ownership is always a mediator of the relationship between the appointment and the return. The result also suggests that the ratio of exports to sales is a positive intermediate of the appointment and the return.

[Insert Table 6 here]

\footnotetext{
${ }^{21}$ SK was the third largest chaebols.
} 


\subsection{Further robustness tests}

In addition to the estimation using different models and frequency of data, we undertake two further analyses to check the robustness of our findings. First, we examine the effect of the appointment of outside directors using the Jensen-alpha method, whereby the difference in the returns between the treated and its predicted returns by the CAPM estimation within the preset appointment window. These predicted returns, as counterfactuals, were based on around 45 calendar days of observations using the period from 60 days to 15 days before the appointments. Appointment windows refer to the length of cumulative abnormal returns calculations. Overall, we find from Table 7 that the results are consistent with the results of the BHAR method discussed above.

\section{[Insert Table 7 here]}

Second, we examine the appointment effect for the large firms using the regression discontinuity design (RDD) method. The amended Securities and Exchange Act also provides a unique data set for examining the effect of the requirement for outside directors, particularly for large firms. In March 2001, the amended Securities and Exchange Act stipulated that large listed firms, defined as firms with an asset size of no less than two trillion won (approximately two billion US\$), and securities companies, should have no fewer than three outside directors on their board and that no less than half of the board should be comprised of outside members. We regard firm size as a selective variable, with a threshold level of two trillion won, which determines whether listed firms participate in the policy reform (i.e., appoint outside directors). This additional information on the selection variable allows us to estimate the average effect of the treatment (ATT) by the RDD. In other words, we run the following regression only if the selection variable (i.e., asset size) falls into the pre-set band: 


$$
\min _{\delta, \phi} \sum_{i=1}^{N}\left(Y_{i}-\text { const }-\delta \cdot O D_{i}-m_{1}(s, \phi)\right)^{2}
$$

where the binary variable $O D_{i}=1$ if a firm's asset size is no less than two trillion won, and zero otherwise. We specify the function $m_{1}(s)$ as the $4^{\text {th }}$ order polynomial expansion in the selective variable for the parameter of $\phi$ in this unspecified function.

The estimation results in Table 8 confirm that large firms' appointment of no fewer than 50 percent outside directors does not positively affect their returns. Despite firms' prompt compliance with the 50 percent requirement, the estimated coefficients of $\delta_{-} O D^{+}$are not significant across the year, irrespective of the size of the estimation band. We set the length of the bandwidth based on the number of observations (i.e., around 25-30 each side of the threshold) due to the limited number of firms when we apply the 3-5 percent rule for asset size. The insignificant result is also confirmed when we increase the bandwidth to cover all samples (lower panel).

This finding is closely related to the finding on the neutral effect of the appointment of outside directors in chaebol affiliates. In fact, large firms in Korea are closely related to chaebol affiliates. The shares of the 10 largest chaebols' sales and employment in the Korean economy in 2000 were 44.8 percent and 17 percent respectively (KFTC, 2006); and the equity value and number of affiliates of the four largest chaebols in 1999 were 105 trillion won and 153 respectively.

[Insert Table 8 here] 


\section{Concluding Remarks}

Evaluation of securities legislation has become important since the passage of the SOX 2002. In an extension of the existing literature focusing on the case of the U.S., we investigate two issues in Korea where listed firms have experienced a dramatic change in governance systems due to regulatory reforms following the 1997 financial crisis. First, are there positive causal effects of the board reform through the appointment of outside directors on the performance of the share prices in an emerging market where family-run businesses are dominant? Second, is the positive impact, if any, sustainable? Using the program evaluation methodologies and annual/daily panel data for Korean firms listed on Korea Exchange covering 1999-2007, we found that:

(a) The benchmark estimation results using 1999-2007 annual data show that the appointment of outside directors only has a positive effect when the number of outside directors compared to board members increases significantly and there is a lead-and-lag effect from the amended Securities and Exchange Laws in the early 2000s. This finding is consistent with Choi et al. (2007). However, this positive effect of the appointment has become insignificant since the mid 2000s if not negative as reported by Ahern and Dittmar (2012);

(b) The positive effect is more evident for independent firms than for chaebol affiliates when we use daily data for the year 2000, which passes the endogeneity test, and after controlling for size effects. Further investigation suggests that the positive effect is less evident when a firm has a high level of chaebol characteristics, such as circular cross-firm shareholdings and a high disparity between the CSH's ownership and managerial control. 
(c) The lack of evidence on the sustained effects of the appointment of outside directors may result from the shareholders' observation of the diminishing marginal productivity of outside directors as the number of the appointed outside directors increases; the increased transaction costs of the appointment caused by the slow development of market for outside directors compared to the sharply increased demand for them; and high monitoring costs to outsiders associated with the complex ownership of chaebol affiliates. The market's suspicion about the 'independence' of outside directors as opposed to the powerful CSHs of chaebols could be another reason. Alternatively, as Castro, Clementi, and MacDonald's (2004) model indicates, investors place less importance on the positive short-run demand effect on growth than on the negative long-run economic growth caused by improved investor protection, which in turn causes a decline in (entrepreneurs') savings and investment. 


\section{References}

Abadie, A., and Imbens, G. (2006), 'Large sample properties of matching estimators for average treatment effects,' Econometrica, 74, 235-267.

Adams, R.B., and Ferreira, D., (2007), 'A theory of friendly firms.' Journal of Finance 62(1): 217-250.

Ahern, K.R. and Dittmar, A.K. (2012), 'The changing of the boards: The impact of firm valuation of mandated female board representation,' Quarterly Journal of Economics 127: 137197.

Aman, H. and Nguyen, P. (2008), 'Do stock prices reflect the corporate governance quality of Japanese firms?' Journal of the Japanese and International Economies, 22(4):647-662.

Ananchotikul, S. and Eichengreen, B. (2009), 'Corporate governance reform in emerging markets: How much, why, and with what effects?' Journal of the Japanese and International Economies, 23(2):149-176.

Aoki, M., and Jackson, G. (2008), 'Understanding an emergent diversity of corporate governance and organisational architecture: an essentiality-based analysis,' Industrial and Corporate Change, 17:1-27.

Armstrong, C., Guay, W. and Weber, J. (2010), 'The role of information and financial reporting in corporate governance and debt contracting,' Working paper, University of Pennsylvania and Massachusetts Institute of Technology.

Bae, K-H, Kang, J-K. and Kim, J-M. (2002), 'Tunnelling or value added? Evidence from mergers by Korean business groups,' Journal of Finance, 57(6), 2695-2740.

Bebchuk, L.A., and Row, M.J. (1999), 'A theory of path dependence in corporate governance and ownership,' Stanford Law Review, 52:127.

Bebchuk, L.A., and Weisbach, M.S. (2010), 'The state of corporate governance research,' Review of Financial Studies, 22(2), 783-827.

Benston, G. (1973), 'Required disclosure and the stock market: an evaluation of the Securities Exchange Act of 1934,' American Economic Review, 63, 132-155.

Black, B. S. Jang, H., and Kim, W. (2006), 'Does corporate governance predict firms' market values? Evidence from Korea.' Journal of Law, Economics and Organisation, 22: 366-413.

Black, B.S. and Kim, W. (2012), 'The effect of board structure on firm value: a multiple identification strategies approach using Korean data.' Journal of Financial Economics, 104:203226. 
Brickley, J.A., and Zimmerman, J.L. (2010), 'Corporate governance myths: Comments on Armstrong, Guay and Weber,' Journal of Accounting and Economics, 50, 235-245.

Bushee, B.J., and Leuz, C. (2005), 'Economic consequences of SEC disclosure regulation: evidence from the OTC bulletin board,' Journal of Accounting and Economics, 39, 233-264.

Castro, R., Clementi, G.L. and MacDonald, G. (2004), 'Investor protection, optimal incentives and economic growth,' Quarterly Journal of Economics, 119, 1131-1175.

Chhaochharia, V., and Grinstein, Y. (2007), 'Corporate governance and firm value: the impact of the 2002 governance rules,' Journal of Finance, 62, 1789-1825.

Choi, J., Park, S. and Yoo, S., (2007), 'The value of outside directors: Evidence from corporate governance reform in Korea,' Journal of Financial and Quantitative Analysis 42, 941-962.

Claessens, S., Djankov, S. and Lang, L.H.P. (2000), 'The separation of ownership and control in East Asian corporations,' Journal of Financial Economics, 58(1-2), 81-112.

Demsetz, H., and Lehn, K. (1985), 'The structure of corporate ownership: Causes and consequences,' Journal of Political Economy, 93:1156-1177.

DeFond, M.L., and Lennox, C.S. (2011), 'The effects of SOX on small auditor exits and audit quality,' Journal of Accounting and Economics, 52:21-40.

Dey, A. (2010), 'The chilling effect of Sarbane-Oxley: A discussion of Sarbane-Oxley and corporate risk-taking,' Journal of Accounting and Economics, 49, 53-57.

Dixit, A. (2009), 'Governance institutions and economic activity,' American Economic Review, 99(1), 5-24.

Doidge, C., Karolyi, G.A. and Stulz, R.M. (2007), 'Why do countries matter so much for corporate governance,' Journal of Financial and Economics, 86, 1-39.

Duchina, R., Matsusaka, J.G. and Ozbas, O. (2010), 'When are outside directors effective?'Journal of Financial Economics, 96(2), 195-214.

Durnev, A., and Kim, E-H. (2005), 'To steal or not to steal: Firm attributes, legal environment and valuation, ' Journal of Finance, 60(2), 1461-93.

Fama, E.F., and Jensen, M.C. (1983), 'Separation of ownership and control,' Journal of Law and Economics, 26(2), 301-325.

Ferris, S.P., and Yan, X. (2007), 'Do independent directors and chairmen matter? The role of boards of directors in mutual fund governance,' Journal of Corporate Finance, 13, 392-420. 
Gompers, P., Ishi, J. and Metrick, A. (2003), 'Corporate governance and equity prices,' Quarterly Journal of Economics, 118, 107-155.

Greenstone, M., Oyer, P. and Vissing-Jorgensen, A. (2006), 'Mandated disclosure, stock returns, and the 1964 Securities Acts amendments,' Quarterly Journal of Economics, 121 (2), 399-460.

Gul, F.A., Srinidhi, B. and Ng, A.C. (2011), 'Does board gender diversity improve the informativeness of stock prices?' Journal of Accounting and Economics, 51:314-338.

Imbens, G., and Lemieux, T. (2008), 'Regression discontinuity designs: A guide to practice,' Journal of Econometrics, 142, 615-635.

Imbens, G., and Wooldridge, J.M. (2009), 'Recent Developments in the Econometrics of Program Evaluation,' Journal of Economic Literature, 47(1), 5-86.

Jain, P.K., and Rezaee, Z. (2006), 'The Sarbane-Oxley Act of 2002 and capital-market behaviour: Early evidence,' Contemporary Accounting Research, 23, 629-654.

Joh, S.W. (2003), 'Corporate governance and profitability: Evidence from Korea before the economic crisis,' Journal of Financial Economics, 68, 287-322.

Johnson, Simon, Rafael La Porta, Florencio Lopez-de-Silanes, and Andrei Shleifer, (2000), '”Tunnelling,"' American Economic Review Papers and Proceedings, 90: 22-27.

Kang, H.C., Binh, K.B., Cho, S.H., and J. Yun, J. (2007), A Study on the Measurement of Business Groups' Ownership Disparity: Critical threshold control method. Research Report \#07-03, Korea Securities Research Institute, Seoul: Korea.

Kim, E., and Kim, W. (2008), 'Changes in Korean Corporate Governance: A response to crisis,' Journal of Applied Corporate Finance, 20(1), 47-58.

Kim, E. (2006). "The impact of family ownership and capital structures on productivity performance of Korean manufacturing firms: Corproate governance and the "chaebol problem", Journal of the Japanese and International Economies, 20(2):209-233.

Korea Fair Trade Commission. (2006), 'Examination of market structure in 2004,' KFTC, Media Report (07/13).

Kothari, S.P., and Warner, J.B. (2007), 'Econometrics of event studies,' In Eckbo, B.E. (ed.), Handbook of Corporate Finance: Volume 1, Elsevier: Amsterdam.

La Porta, R., Lopez-de-Silanes, F., Shleifer, A. and Vishny, R. (2002), 'Investor protection and corporate valuation,' Journal of Finance, 58, 1147-1170.

Li, J.S. (2003), 'Relation-based versus rule-based governance: An explanation of the East Asian miracle and Asian crisis,' Review of International Economics, 11(4), 651-673. 
Li, H., M. Pincus, and Rego, S. (2008), 'Market reaction to events surrounding the SarbaneOxley Act of 2002 and earnings management,' Journal of Law and Economics, 51, 111-134.

Linck, J., J. Netter, and Yang, T. (2009), 'The effect and unintended consequences of the Sarbane-Oxley Act on the supply and demand for directors,' Review of Financial Studies, 32, 3287-3328.

Lhuillery, S. (2011), 'The impact of corporate governance practices on R\&D efforts: a look at shareholders' rights, cross-listing, and control pyramid,' Industrial and Corporate Change, 20:1475-1513.

Lyon, J., Barber, B. and Tsai, C. (1999), 'Improved methods of tests of long-horizon abnormal stock returns,' Journal of Finance, 54, 165-201.

Min, B.S. and Verhoeven, P. (2013), 'Outsider board activity, ownership structure and firm value: Lessons from Korea,' Internatioal Financial Review, forthcoming.

Mitsudome, T. and Weintrop, J. and Hwang, L-S. (2008), 'The relation between changes in CEO compensation and firm performance: A Japanese/American comparion,' Journal of the Japanese and International Economies, 22(4): 605-619.

Mitton, T. (2002), 'A cross firm analysis of the impact of corporate governance on the East Asian financial crisis,' Journal of Financial Economics, 64, 215-241.

Miyajima, H. (2008), 'The performance effects and determinants of reform,' in Aoki, M., G. Jackson, H. Miyajima, (Eds.). Corporate Governance in Japan, Oxford University Press: New York.

Morck, R., Wolfenzen, D. and Yeung, B. (2005), 'Corporate governance, economic entrenchment and growth,' Journal of Economic Literature, 43, 657-722.

Park, Y.W., and Shin, H-H. (2004), 'Board composition and earnings management in Canada,' Journal of Corporate Finance, 10, 431-457.

Pfeffer, J. and Salancik, G.R., (1978), The External Control of Organisations: A Resource Dependence Perspectiv. Harper \& Row: New York.

Siebels, J-F. and Knyphausen-Aufseb, D.Z., (2012), A Review of theory in family business research: The implications for corporate governance, International Journal of Management Reviews, 14(3): 280-304.

Sokolyk, T. (2011), 'The effects of antitakeover provisions on acquisition targets,' Journal of Corporate Finance, 17(3), 612-627. 
Stigler, G.J. (1964), 'Public regulation of the securities markets,' Journal of Business, 37(2), 117-142.

Yermack, D. (1996), 'Higher market valuation of companies with a small board of directors,' Journal of Financial Economic, 40, 185-211.

Young, M.N., Peng, M.W., Ahlstrom, D., Bruton, G.D., and Jiang, Y. (2008), 'Corporate governance in emerging economies: A review of the principal-principal perspective,' Journal of Management, 45:196-220.

Zhang, I.X. (2007), 'Economic consequences of the Sarbane-Oxley Act of 2002,' Journal of Accounting and Economics, 44, 74-115. 


\section{Appendix 1. The difference-in-differences estimator}

The basic concept of the identification of the DID estimator is explained by $2 \times 2$ case (see Table A1). The first 2 refers to two groups of listed companies (i.e. treatment vs. control group: $G \in\{T, C\}$ ) and the second 2 refers to the division into two periods of time (i.e. before and after the appointment of outside directors: $t \in\{1,2\}$ ). Participation in the program, which is supposed to be introduced at the end of period 1, divides the observations between groups $T$ and $C$. The binary variable indicating the introduction of the program $(P)$ will be 0 in period 1 and unitary in period 2 .

Table A1: 2 x 2 Matrix for Difference-in-Difference Estimator

Time 2: After the appointment of outside directors

Time 1: Before the appointment of outside directors

\begin{tabular}{|l|l|}
\hline Group $C$ : Control group & \multicolumn{1}{l}{ Group $T$ : Treatment group } \\
\hline$R_{t=2}^{C}$ & Treated \\
\hline & $R_{t=2}^{T}$ \\
\hline$R_{t=1}^{C}$ & \\
\hline
\end{tabular}

The model requires $N$ observations on $(R, t, G)$ where $R$ is the outcome variable (i.e., returns). In the figure above, group $G=T$ in period $t=2$ is the only group/period exposed to the program (i.e., the appointment of outside directors). The figure also indicates that in period $t=2$ (i.e., after the appointment of outside directors), researchers can observe only one (ex post) outcome variable:

$\left.\begin{array}{l}R_{t=2}^{T} \\ R_{t=2}^{C}\end{array}\right\}$ or

where $R_{t=2}^{T}$ is the outcome (returns) caused by the appointment of outside directors (i.e., receiving treatment) and this is observed if $G=T, t=2 ; R_{t=2}^{C}$ is the outcome from the control group, and this is observed if $G=C, t=2$. Given the impossibility of the simultaneous observation of both $R_{t=2}^{T}$ ' and' $R_{t=2}^{C}$, the DID estimators compare treatment units with control units after adjusting for stable characteristics that may affect the cross-sectional level of the response variable (i.e., returns). 
Table 1. Election of outside directors: corporate listed on the Korea exchange (\%)

This table reports election of outside directors of corporations listed on the Korea exchange during 1999-2007. The discrepancies, if any, between the total number at the bottom and those in row 3 are due to rounding errors. Compilation was based on the KLCA database. We dropped firms if the size of the BOD was zero.

\begin{tabular}{|c|c|c|c|c|c|c|c|c|c|}
\hline & 1999 & 2000 & 2001 & 2002 & 2003 & 2004 & 2005 & 2006 & 2007 \\
\hline $\begin{array}{l}\text { Total Listed } \\
\text { Corporations }\end{array}$ & 100 & 100 & 100 & 100 & 100 & 100 & 100 & 100 & 100 \\
\hline $\begin{array}{l}\text { Firms without an } \\
\text { outside director }\end{array}$ & 66.0 & 37.7 & 34.6 & 29.6 & 22.4 & 23.6 & 17.9 & 17.6 & 5.7 \\
\hline $\begin{array}{l}\text { Firms with at least } \\
\text { one outside director } \\
\text { No. of outside } \\
\text { directors per firm }\end{array}$ & 34.0 & 62.3 & 65.4 & 70.4 & 77.6 & 76.4 & 82.1 & 82.4 & 94.3 \\
\hline$=1$ & 16.4 & 19.0 & 22.5 & 22.8 & 24.1 & 23.5 & 26.9 & 28.1 & 32.4 \\
\hline$=2$ & 10.2 & 27.0 & 28.1 & 30.1 & 32.5 & 31.0 & 32.5 & 29.1 & 33.7 \\
\hline$\geq 3$ & 7.3 & 16.3 & 14.7 & 17.5 & 21.1 & 22.0 & 22.8 & 25.2 & 28.1 \\
\hline
\end{tabular}




\section{Figure 1. Trends in the size of BOD, number of outside directors and ratio of outside directors to BOD for listed firms}

This figure shows trends in the size of BOD, number of outside directors and ratio of outside directors to BOD for listed firms on the Korea Exchagne. The left and right axes refer to the number of members on the BOD and the number of outside directors, and the ratio of outside directors/BOD, respectively.

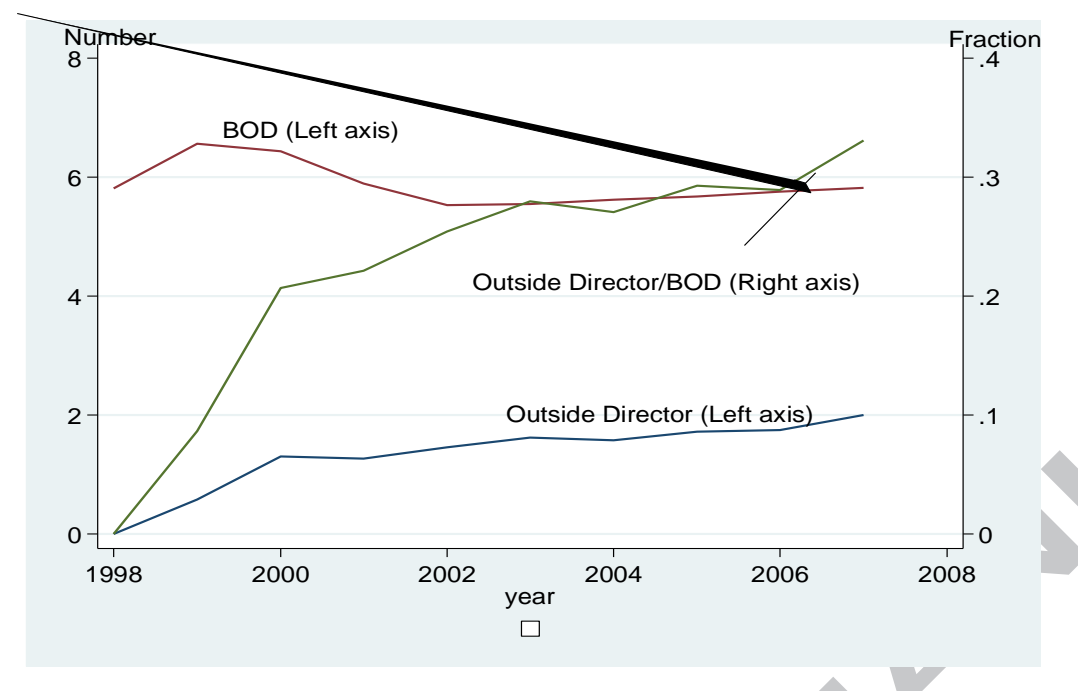

Figure 2. Trends in the proportion of outside directors on the BOD by type of firms and ratio

These figure show trends in the proportion of outside directors on the BOD by type of firms and ratio. The vertical figures on the left (right) refer to the share of listed firms with the ratio of outside directors to total directors on the BOD at least 50 (25) percent.

Panel A. The 50\% Rule

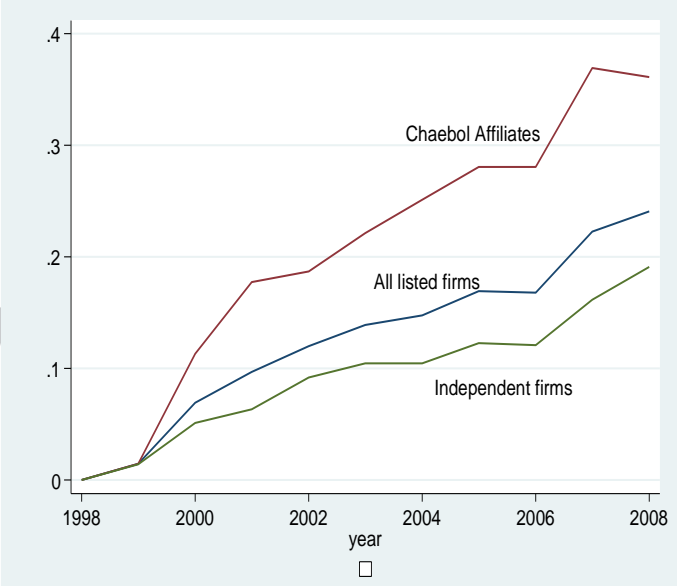

Panel B. The 25\% Rule

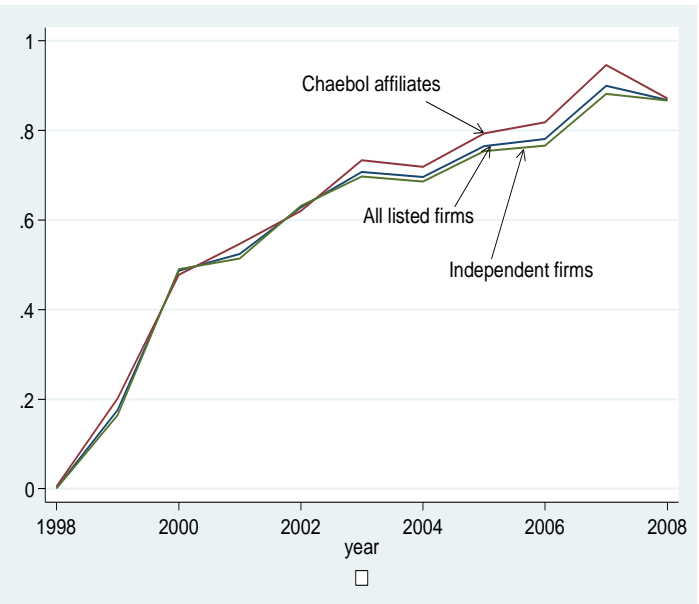


Table 2. Difference-in-differences estimation results of the board reforms for selected years This table reports difference-in-differences estimation result of the board reforms for selected years. Dependent variables are continuously compounded returns. $\delta_{-} O D^{+}$is defined as 1 if the firm appointed new outside director(s) and 0 otherwise; $\delta_{-} O D^{-}$is defined as 1 if the firm decreased the number of outside director(s) and 0 otherwise; $\delta_{-} O D^{50 \%}$ is defined as 1 if the firm complied the 50 percent rule and 0 othersise; and $\delta_{-} O D^{25 \%}$ is defined as 1 if the firm complied the 25 percent rule and 0 otherwise. p-values in brackets are based on the HuberWhite adjusted standard errors. Estimation model is $E\left(R_{i t} \mid O D\right.$, Time $)=$ const $+\beta_{1} \cdot T_{t}+\beta_{2} \cdot O D_{i}+\delta \cdot T_{t} \times O D_{i}$, where $\mathrm{T}$ is 1 if time (i.e., year) belongs to post appointment time/ post decrease time/ post compliance of the 50 percent rule/post compliance of the 25 percent rule. OD is the binary variables for the $\delta_{-} O D^{+}, \delta_{-} O D^{-}$, $\delta_{-} O D^{50 \%}$, and $\delta_{-} O D^{25 \%}$ defined as above. Only interaction terms are presented. Estimation results for 2004-2005 are not significant and are not shown for brevity. Other regressors, including constants, are not shown here for brevity.

Panel A: 1999-2000

Panel B: 2000-2001
(1)
(2)
(3)
(4)
(1)
(2)
(3)
(4)

\begin{tabular}{|c|c|c|c|c|c|c|c|c|}
\hline$\delta_{-} O D^{+}$ & $\begin{array}{c}-0.017 \\
{[0.917]}\end{array}$ & & & & $\begin{array}{c}0.103 * \\
{[0.011]}\end{array}$ & & & \\
\hline$\delta_{-} O D^{-}$ & & $\begin{array}{c}0.000 \\
{[0.999]}\end{array}$ & & & & $\begin{array}{c}-0.011 \\
{[0.805]}\end{array}$ & & \\
\hline$\delta_{-} O D^{50 \%}$ & & & $\begin{array}{c}0.206 \\
{[0.505]}\end{array}$ & & & & $\begin{array}{r}0.135 \\
{[0.130]}\end{array}$ & \\
\hline$\delta_{-} O D^{25 \%}$ & & & & $\begin{array}{c}0.078 \\
{[0.643]}\end{array}$ & & & & $\begin{array}{c}0.028 \\
{[0.510]}\end{array}$ \\
\hline$R^{2}$ & 0.013 & 0.013 & 0.014 & 0.014 & 0.012 & 0.007 & 0.011 & 0.008 \\
\hline $\mathrm{N}$ & 820 & 820 & 820 & 820 & 960 & 960 & 960 & 960 \\
\hline
\end{tabular}

Panel C: 2003-2004

Panel D: 2006-2007

(1)

(2)

(3)

(4)

(1)

(2)

(3)

(4)

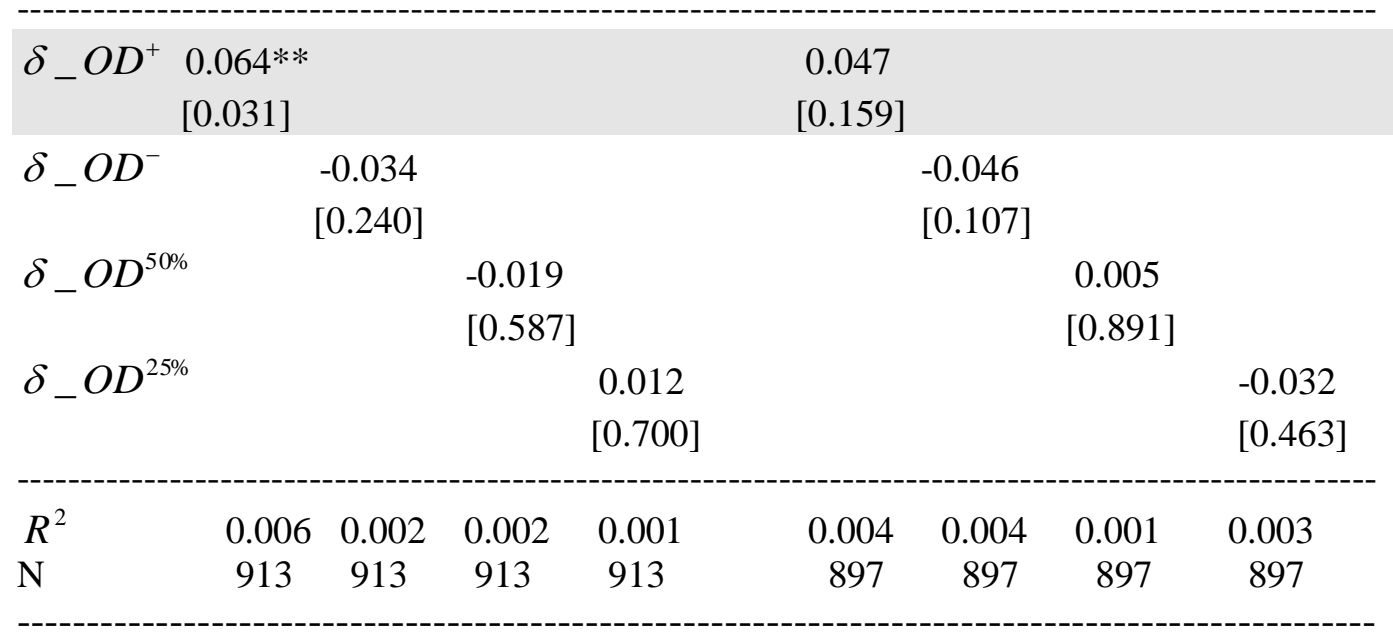




\section{Table 3. Returns and the firm's decision on the appointment of outside directors}

This table reports returns and the firm's decision on the appointment of outside directors. Dependent variables are continuously compounded returns. $\delta_{-} O D^{+}$is defined as 1 if the firm appointed new outside director(s) and 0 otherwise; Ln_size is measured by natural logarithm of equity capital, and its squared terms (Ln_size2); Book/Market is measured by book value per share divided by the average market price per share; Performance is measured by the two-year average of industry-demeaned profits in assets; dummy indicating chaebol affiliates (D_affiliate); Foreign Debt is measured by foreign debt divided by total liabilities; Bank Dependence is measured by borrowing divided by total liabilities; Capital Market Dependence is measured by bond financing divided by total liabilities; Market Power is measured by advertising expenditure divided by sales; Employee Growth is measured by the ratio of change in the number of employees to total employment; Bank Share is measured by the ratio of bank-owned shares. We expect this to be $\{-\}$ for the same reason as that given for the firm's reliance on banks; Crossfirm Share is measured by the ratio of stocks owned by other non-financial firms; Foreigners Share is measured by the ratio of foreign investors' share ownership to total share ownership. Columns (1) and (1)' are estimated by treatment regression, whereas (2) and (3) by instrument variable using the GMM and LIML methods, respectively. Columns (4), (5) and (6) were estimated by the logit model, the Poisson model and the negative binomial model, respectively. p-values in brackets are based on Huber-White heteroskedacity adjusted estimator: $* * *, * *$ and $*$ denote the $1 \%, 5 \%$ and $10 \%$ levels, respectively. Rho refers to correlation between the error terms in the structural and participation equations. $\chi^{2}(1)$ in col. (1) refers to statistics for model independence of the error terms between the return and the firm's decision equations. $\chi^{2}(1)$ in col. (2) refers to statistics for the null of exogeneity of the binary appointment variable. Alpha refers to statistics for the null of equi-dispersion on the Poisson estimation. OID refers to statistics for the over identification test. Constants are not shown for brevity.

\begin{tabular}{|c|c|c|c|c|c|c|c|}
\hline & \multicolumn{3}{|c|}{ Panel A: Return } & \multicolumn{4}{|c|}{ Panel B: Firm's Participation Equation } \\
\hline & (1) & (2) & (3) & $(1)^{\prime}$ & (4) & (5) & (6) \\
\hline$\delta_{-} O D^{+}$ & $\begin{array}{c}0.10 * * * \\
{[0.000]}\end{array}$ & $\begin{array}{l}0.06 * * \\
{[0.033]}\end{array}$ & $\begin{array}{c}0.09 * \\
{[0.084]}\end{array}$ & & & & \\
\hline Ln_size & $\begin{array}{c}0.00 \\
{[0.946]}\end{array}$ & $\begin{array}{c}-0.00 \\
{[0.835]}\end{array}$ & $\begin{array}{c}0.00 \\
{[0.908]}\end{array}$ & $\begin{array}{c}0.99 \\
{[0.116]}\end{array}$ & $\begin{array}{r}0.37 \\
{[0.721]}\end{array}$ & $\begin{array}{r}-0.14 \\
{[0.849]}\end{array}$ & $\begin{array}{c}-0.26 \\
{[0.728]}\end{array}$ \\
\hline Book/Market & $\begin{array}{c}0.00 \\
{[0.847]}\end{array}$ & $\begin{array}{l}-0.00 \\
{[0.876]}\end{array}$ & $\begin{array}{c}0.00 \\
{[0.840]}\end{array}$ & & & & \\
\hline Performance & $\begin{array}{c}-0.00 \\
{[0.850]}\end{array}$ & $\begin{array}{c}0.02 \\
{[0.461]}\end{array}$ & $\begin{array}{l}0.00 \\
{[0.559]}\end{array}$ & & & & \\
\hline Ln_size2 & & & & $\begin{array}{c}-0.03 * \\
{[0.100]}\end{array}$ & $\begin{array}{c}-0.01 \\
{[0.693]}\end{array}$ & $\begin{array}{c}0.01 \\
{[0.718]}\end{array}$ & $\begin{array}{c}0.01 \\
{[0.597]}\end{array}$ \\
\hline \multicolumn{4}{|l|}{ D_affiliates } & $\begin{array}{c}0.19 \\
{[0.124]}\end{array}$ & $\begin{array}{c}0.18 \\
{[0.444]}\end{array}$ & $\begin{array}{c}0.08 \\
{[0.612]}\end{array}$ & $\begin{array}{c}0.05 \\
{[0.751]}\end{array}$ \\
\hline \multicolumn{4}{|l|}{ Foreign Debt } & $\begin{array}{c}1.11 \\
{[0.411]}\end{array}$ & $\begin{array}{r}4.32 * \\
{[0.055]}\end{array}$ & $\begin{array}{r}3.68 * * * \\
{[0.001]}\end{array}$ & $\begin{array}{l}3.68 * * * \\
{[0.002]}\end{array}$ \\
\hline \multicolumn{4}{|c|}{ Bank Dependence } & $\begin{array}{l}-0.06 \\
{[0.851]}\end{array}$ & $\begin{array}{c}-0.88 \\
{[0.167]}\end{array}$ & $\begin{array}{c}-0.49 \\
{[0.323]}\end{array}$ & $\begin{array}{c}-0.50 \\
{[0.306]}\end{array}$ \\
\hline \multicolumn{4}{|c|}{ Capital Market Dependence } & $\begin{array}{l}1.21 * * * \\
{[0.002]}\end{array}$ & $\begin{array}{c}1.25 \\
{[0.102]}\end{array}$ & $\begin{array}{c}0.49 \\
{[0.281]}\end{array}$ & $\begin{array}{c}0.46 \\
{[0.316]}\end{array}$ \\
\hline \multicolumn{4}{|l|}{ Market Power } & $\begin{array}{c}-0.03 \\
{[0.326]}\end{array}$ & $\begin{array}{c}0.02 \\
{[0.749]}\end{array}$ & $\begin{array}{c}-0.02 \\
{[0.602]}\end{array}$ & $\begin{array}{c}-0.02 \\
{[0.588]}\end{array}$ \\
\hline \multicolumn{4}{|c|}{ Employee Growth } & $\begin{array}{c}0.00 \\
{[0.753]}\end{array}$ & $\begin{array}{r}0.00 \\
{[0.457]}\end{array}$ & $\begin{array}{r}0.00 \\
{[0.187]}\end{array}$ & $\begin{array}{c}0.00 \\
{[0.224]}\end{array}$ \\
\hline \multicolumn{4}{|l|}{ Bank Share } & $\begin{array}{c}-0.01 * * \\
{[0.030]}\end{array}$ & $\begin{array}{l}-0.02 * \\
{[0.075]}\end{array}$ & $\begin{array}{c}-0.01 * * \\
{[0.047]}\end{array}$ & $\begin{array}{c}-0.02 * * \\
{[0.048]}\end{array}$ \\
\hline \multicolumn{4}{|c|}{ Crossfirm Share } & $\begin{array}{c}-0.01 * \\
{[0.065]}\end{array}$ & $\begin{array}{c}-0.01 \\
{[0.119]}\end{array}$ & $\begin{array}{c}-0.00 \\
{[0.404]}\end{array}$ & $\begin{array}{c}-0.00 \\
{[0.286]}\end{array}$ \\
\hline \multicolumn{4}{|c|}{ Foreigners Share } & 0.01 & -0.00 & -0.00 & -0.00 \\
\hline
\end{tabular}




\begin{tabular}{lccccccc} 
& & & & {$[0.149]$} & {$[0.773]$} & {$[0.509]$} & {$[0.547]$} \\
\hdashline $\mathrm{N}$ & 384 & 384 & 384 & 384 & 436 & 436 & 436 \\
Pseudo $R^{2}$ & & & & & - & 0.04 & - \\
$\log$ likelihood & 253.1 & - & - & - & -285.3 & -496.1 & -482.0 \\
$\rho$ & -0.77 & & & & & & \\
$\chi^{2}(1)$ & $44.61 * * *$ & $4.55 * *$ & $4.55^{* *}$ & & & & \\
alpha & & & & & - & $0.70 * * *$ & - \\
OID $\left(\chi^{2}(9)\right)$ & - & 7.57 & 7.47 & & & &
\end{tabular}

\section{Table 4. Estimation BHAR for the treated firms, chaebols and independent firms}

This table reports estimation BHAR for the treated firms, chaebols and independent firms. The abnormal return for BHAR, as dependent variable, is measured by the difference between geometric mean returns of each treated firm and geometric mean returns of the market portfolio within the preset appointment window. The appointment window, either 7 or 9 calendar days, refers to the length of the abnormal return calculation. $* * *, * *$ and $*$ denote the $1 \%, 5 \%$ and $10 \%$ levels, respectively. The P-value in brackets is based on Huber-White heteroskedacity adjusted estimator. Size and performance are measured by equity capital and two-year average of the industry-mean-centred profits prior to the event year for firm performance, respectively. $\chi^{2}(1)$ values are for the Hausman test for the null: estimated parameters between the two groups are equal.

(1)

All firms
(2)
Chaebol affiliates Independent firms

Appointment window: 7 days

(1) Firm size

$\begin{array}{lccc}0.006^{* * *} & 0.003 & 0.008 * * * \\ {[0.003]} & {[0.394]} & 3.57 * & {[0.002]}\end{array}$

$\chi^{2}(1)$

0.002

0.004

(2) Firm performance

$\begin{array}{ccc}0.003 & 0.002 & 0.004 \\ {[0.160]} & {[0.571]} & {[0.180]}\end{array}$

$\chi^{2}(1)$

0.10

Appointment window: 9 days

(1) Firm size

$\begin{array}{ccc}0.005 * * * & 0.002 & 0.007 * * * \\ {[0.000]} & {[0.398]} & 5.09 * *\end{array}$

$\chi^{2}(1)$

0.000

0.003

(2) Firm performance

$$
\begin{gathered}
0.002 \\
{[0.245]}
\end{gathered}
$$

[0.962]

$\chi^{2}(1)$

1.81

$\mathrm{N}$ 


\section{Table 5. Estimation of BHAR for the treated firms by circular cross-firm share, disparity between ownership and control and number of statutory auditors}

This table reports estimation of BHAR for the treated firms by circular cross-firm share, disparity between ownership and control, and number of statutory auditors. The abnormal return for BHAR, as dependent variable, is measured by the difference between geometric mean returns of each treated firm and geometric mean returns of the market portfolio within the preset appointment window. The appointment window, either 7 or 9 days, refers to the length of abnormal calculation. $* * *, * *$ and $*$ denotes the $1 \%, 5 \%$ and $10 \%$ levels, respectively. The P-value in brackets is based on Huber-White heteroskedacity adjusted estimator. Criterion for high and low are based on mean values. Size and performance are measured by equity capital and two-year average of the industry-mean-centred profits prior to the event year for firm performance, respectively. $\chi^{2}(1)$ values are for the Hausman test for the null: estimated parameters between the two groups are equal.

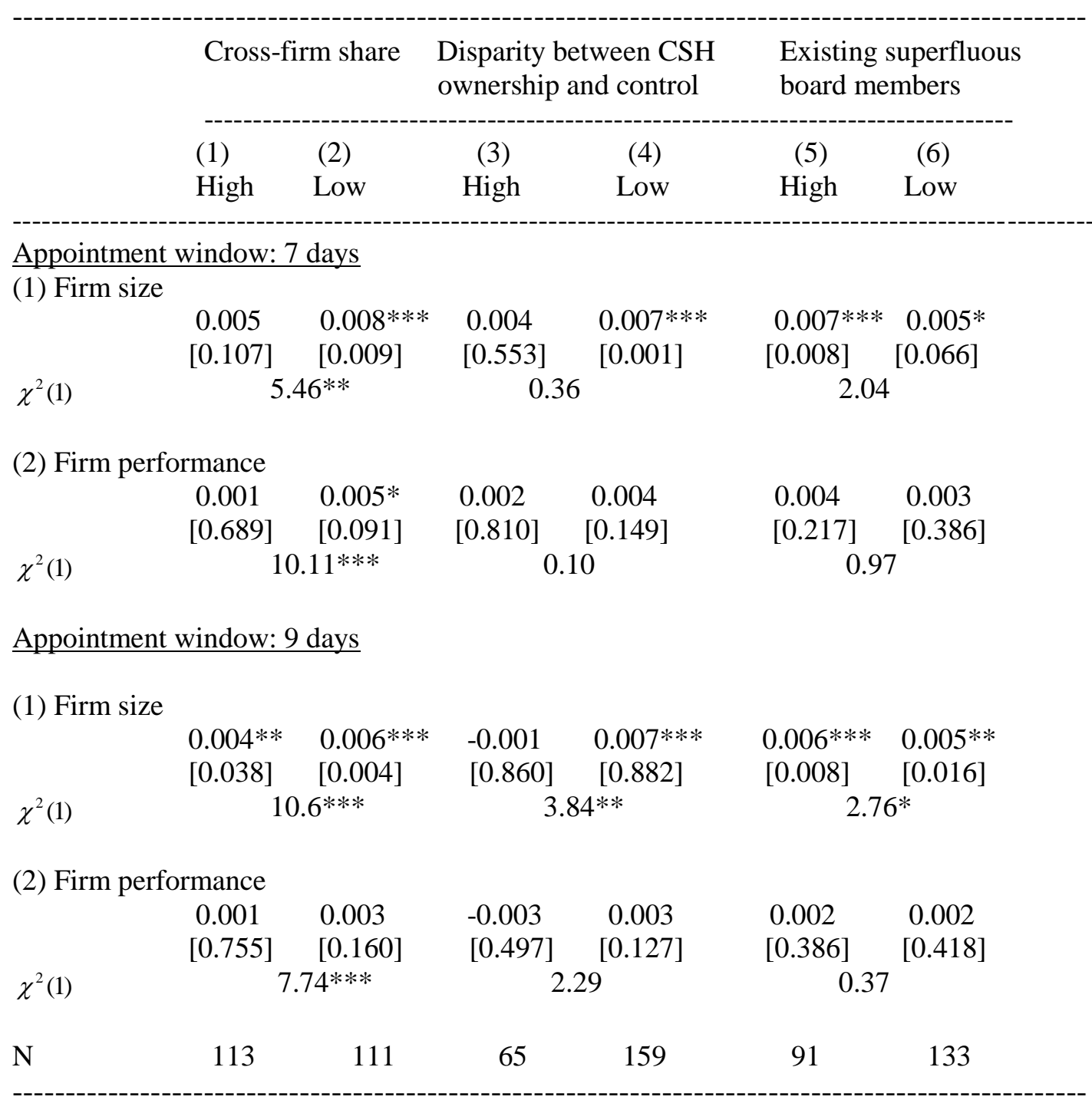




\section{Table 6. Estimation of BHAR for the treated firms by ownership and export ratio}

This table reports estimation of BHAR for the treated firms by ownership and export ratio. The abnormal return for BHAR, as dependent variable, is measured by the difference between geometric mean returns of each treated firm and geometric mean returns of the market portfolio within the preset appointment window. The appointment window, either 7 or 9 days, refers to the length of abnormal calculation. ***, ** and * denotes the $1 \%, 5 \%$ and $10 \%$ levels, respectively. The P-value in brackets is based on Huber-White heteroskedacity adjusted estimator. Criterion for the high and low are based on mean values. Size and performance are measured by equity capital and two-year average of the industry-mean-centred profits prior to the event year for firm performance, respectively. $\chi^{2}(1)$ values are for the Hausman test for the null: estimated parameters between the two groups are equal.

Foreign ownership Export/Sales

\begin{tabular}{|c|c|c|}
\hline & (2) & (3) \\
\hline High & Low & High \\
\hline
\end{tabular}

Appointment window: 7 days

(1) Firm size

$\begin{array}{cccc}0.006^{* *} & 0.006^{* *} & 0.006^{* *} & 0.007 * * \\ {[0.029]} & {[0.045]} & {[0.026]} & {[0.044]}\end{array}$

$\chi^{2}(1)$ 0.001 1.93

(2) Firm performance

\begin{tabular}{cccc}
0.005 & 0.002 & 0.001 & 0.005 \\
{$[0.139]$} & {$[0.586]$} & {$[0.633]$} & {$[0.158]$} \\
& $18.90^{* * *}$ & \multicolumn{2}{c}{$2.80^{*}$}
\end{tabular}

Appointment window: 9 days

(1) Firm size

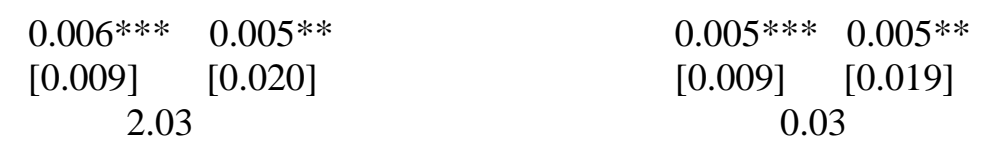

(2) Firm performance

\begin{tabular}{cccc}
0.004 & 0.001 & 0.001 & 0.003 \\
{$[0.144]$} & {$[0.795]$} & {$[0.564]$} & {$[0.301]$} \\
$13.21 * * *$ & \multicolumn{2}{c}{1.07}
\end{tabular}

$\chi^{2}(1)$

$113 \quad 111$

$114 \quad 110$ 


\section{Table 7. Estimation of cumulative abnormal returns by the Jensen-Alpha model in 2000}

This table rerpots estimation of cumulative abnormal returns by the Jensen-Alpha model in 2000 . The cumulative abnormal return, as dependent variable, is calculated by cumulatively adding the difference between each treated firm and the predicted return by the CAPM estimation within the preset appointment window (i.e., either 7 or 9 days). These predicted returns, as counterfactuals, were based on around 45 calendar days of observations using the period from 60 days to 15 days before the appointments. Appointment windows refer to the length of cumulative abnormal returns calculations. $* * *, * *$ and $*$ denote the $1 \%, 5 \%$ and $10 \%$ levels, respectively. The P-value in brackets is based on Huber-White heteroskedacity adjusted estimator.

(1)

All firms
(2)

\section{Chaebol affiliates Independent firms}

Appointment window: 7 days

(1) Firm size

$0.029 * *$

[0.014]

(2) Firm performance

0.019

[0.110]
$-0.004$

[0.867]

$-0.019$

[0.316]
$0.045^{* * *}$

[0.002]

$0.038 * * *$

[0.010]

Appointment window: 9 days

(1) Firm size

$0.038 * * *$

[0.001]

$-0.001$

[0.933]

$0.057 * * *$

(2) Firm performance

$$
0.018
$$

[0.126]

$-0.024$

[0.159]

224

74

$\mathrm{N}$

$0.038 * *$

[0.011]

150 
Table 8. Estimation results for the average treatment on the treated by regression discontinuity design (RDD) for large firms and the 50 percent rule

This table reports estimation results for the average treatment on the treated by regression discontinuity design (RDD) for large firms and the 50 percent rule. Dependent variables are continuously compounded returns. The upper panel shows the RDD estimation results with a band to ensure around 50 observations. The result in the lower panel is the estimation with an infinite band length. P-value in brackets is based on Huber-White heteroskedacity adjusted estimator. The 50 percent rule refers to the legal requirement for large firms, defined as those with asset size of at least two trillion won, to appoint outside directors so that their ratio to total board members is at least 50 percent.

\begin{tabular}{|c|c|c|c|c|c|c|c|c|}
\hline & $\begin{array}{c}(1) \\
2000\end{array}$ & $\begin{array}{c}(2) \\
2001\end{array}$ & $\begin{array}{c}(3) \\
2002\end{array}$ & $\begin{array}{r}(4) \\
2003\end{array}$ & $\begin{array}{c}(5) \\
2004\end{array}$ & $\begin{array}{l}(6) \\
2005\end{array}$ & $\begin{array}{c}(7) \\
2006\end{array}$ & $\begin{array}{c}(8) \\
2007\end{array}$ \\
\hline$\delta_{-} O D^{+}$ & $\begin{array}{c}0.01 \\
{[0.967]}\end{array}$ & $\begin{array}{c}-0.08 \\
{[0.437]}\end{array}$ & $\begin{array}{c}-0.17 \\
{[0.596]}\end{array}$ & $\begin{array}{r}0.06 \\
{[0.686]}\end{array}$ & $\begin{array}{c}0.17 \\
{[0.172]}\end{array}$ & $\begin{array}{c}-0.04 \\
{[0.649]}\end{array}$ & $\begin{array}{c}0.06 \\
{[0.675]}\end{array}$ & $\begin{array}{c}0.00 \\
{[0.984]}\end{array}$ \\
\hline $\begin{array}{l}R^{2} \\
\mathrm{~N}\end{array}$ & $\begin{array}{c}0.22 \\
53\end{array}$ & $\begin{array}{c}0.19 \\
54\end{array}$ & $\begin{array}{c}0.05 \\
45\end{array}$ & $\begin{array}{c}0.20 \\
49\end{array}$ & $\begin{array}{c}0.29 \\
50\end{array}$ & $\begin{array}{c}0.38 \\
50\end{array}$ & $\begin{array}{c}0.11 \\
53\end{array}$ & $\begin{array}{c}0.13 \\
58\end{array}$ \\
\hline$\delta_{-} O D^{+}$ & $\begin{array}{c}0.12 \\
{[0.461]}\end{array}$ & $\begin{array}{c}-0.17 \\
{[0.370]}\end{array}$ & $\begin{array}{c}-0.12 \\
{[0.407]}\end{array}$ & $\begin{array}{c}0.05 \\
{[0.523]}\end{array}$ & $\begin{array}{r}0.01 \\
{[0.946]}\end{array}$ & $\begin{array}{c}-0.04 \\
{[0.732]}\end{array}$ & $\begin{array}{c}-0.01 \\
{[0.905]}\end{array}$ & $\begin{array}{c}-0.05 \\
{[0.519]}\end{array}$ \\
\hline $\begin{array}{l}R^{2} \\
\mathrm{~N}\end{array}$ & $\begin{array}{l}0.02 \\
450\end{array}$ & $\begin{array}{l}0.03 \\
453\end{array}$ & $\begin{array}{l}0.01 \\
438\end{array}$ & $\begin{array}{l}0.02 \\
432\end{array}$ & $\begin{array}{l}0.03 \\
412\end{array}$ & $\begin{array}{l}0.01 \\
409\end{array}$ & $\begin{array}{l}0.01 \\
409\end{array}$ & $\begin{array}{l}0.03 \\
404\end{array}$ \\
\hline
\end{tabular}


Research highlights

- We model Korean listed firms which introduced new outside director system

- We investigated share return in response to the newly introduced outsider system

- The positive impact of the new governance system is observed but not persistent

- Cumulative abnormal return is more evident for independent firms than for chaebol 